
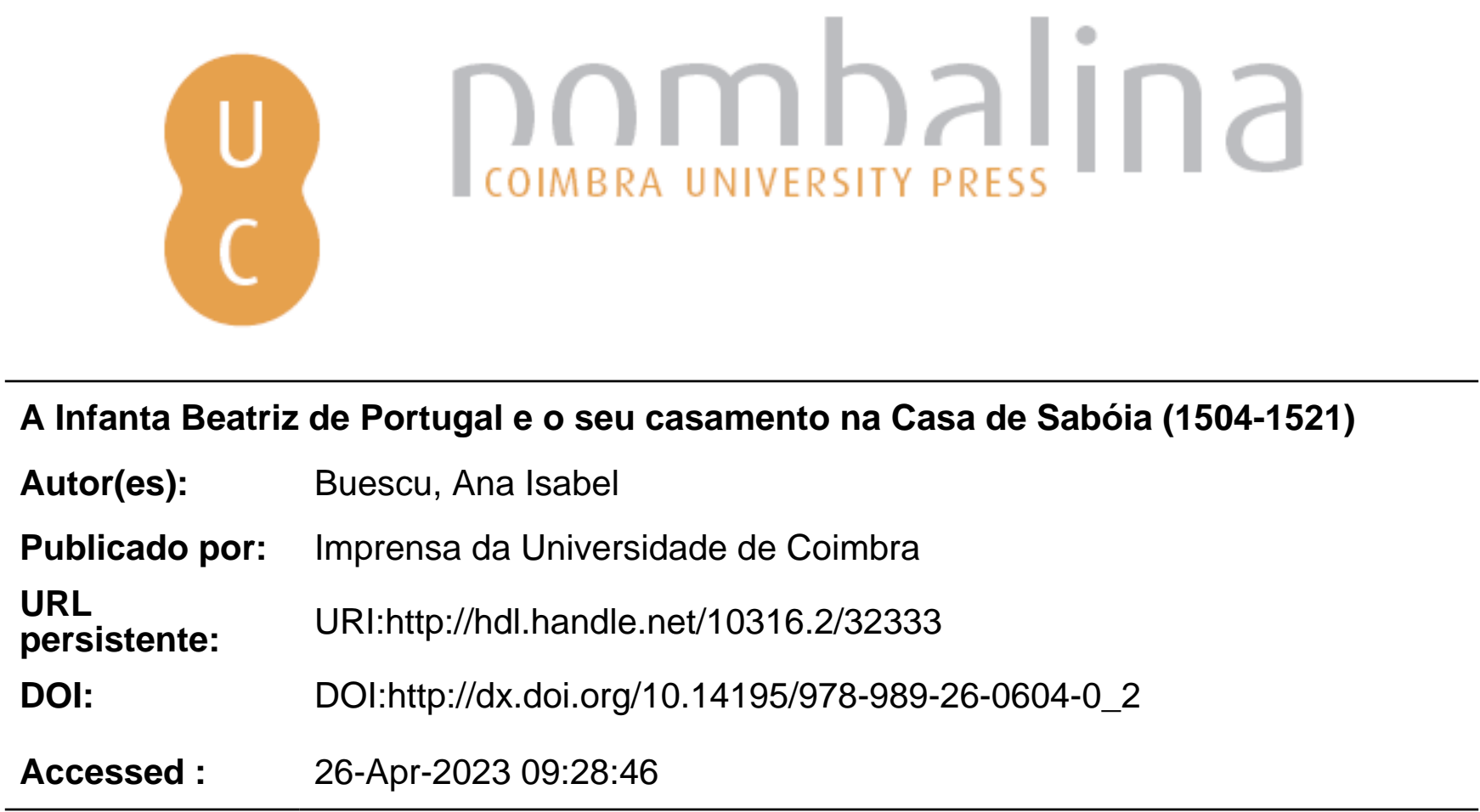

A navegação consulta e descarregamento dos títulos inseridos nas Bibliotecas Digitais UC Digitalis, UC Pombalina e UC Impactum, pressupõem a aceitação plena e sem reservas dos Termos e Condições de Uso destas Bibliotecas Digitais, disponíveis em https://digitalis.uc.pt/pt-pt/termos.

Conforme exposto nos referidos Termos e Condições de Uso, o descarregamento de títulos de acesso restrito requer uma licença válida de autorização devendo o utilizador aceder ao(s) documento(s) a partir de um endereço de IP da instituição detentora da supramencionada licença.

Ao utilizador é apenas permitido o descarregamento para uso pessoal, pelo que o emprego do(s) título(s) descarregado(s) para outro fim, designadamente comercial, carece de autorização do respetivo autor ou editor da obra.

Na medida em que todas as obras da UC Digitalis se encontram protegidas pelo Código do Direito de Autor e Direitos Conexos e demais legislação aplicável, toda a cópia, parcial ou total, deste documento, nos casos em que é legalmente admitida, deverá conter ou fazer-se acompanhar por este aviso. 


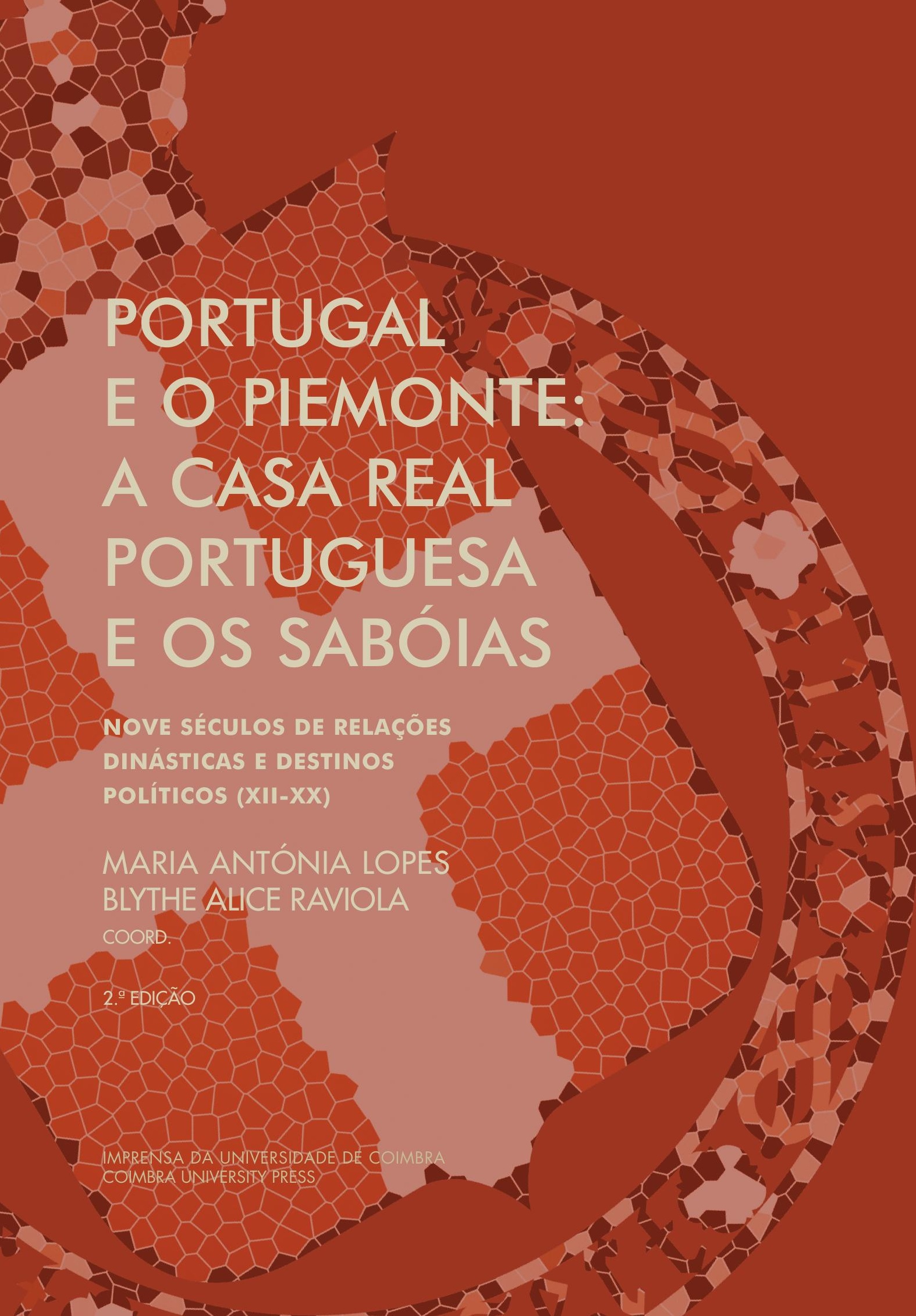


Ana Isabel Buescu

Universidade Nova de Lisboa

\section{A infanta Beatriz de Portugal e O SEU Casamento NA CASA DE SABÓIA (1504-1521)}

Numa quarta-feira, no derradeiro dia do ano de 1504 , nascia nos paços da Alcáçova, em Lisboa, o terceiro filho do rei D. Manuel e da sua segunda mulher, D. Maria, filha dos Reis Católicos. O ambiente então vivido seria em tudo semelhante aos partos anteriores da jovem rainha e aos muitos que haviam de seguir-se até 1516, quando nasceu o seu último filho. Perante a iminência do nascimento, reinavam a ansiedade e a expectativa, cruzando sentimentos vários e múltiplos afazeres: o temor pelo aproximar de um momento de perigo e de incerteza que tantas vezes trazia a morte quer da mãe quer do filho; o juízo dos físicos, a consulta de sinais e dos astros, as orações e a invocação de Maria e dos santos, as relíquias, mas também os preparativos práticos, as águas e os panos, a presença das comadres e parteiras que haviam de ajudar a criança a vir ao mundo, a ansiedade de saber se era rapaz ou rapariga que, apesar das previsões das mais experientes matronas, só o momento do parto desvelava.

O nascimento de uma criança saudável provocava o natural contentamento dos pais e da corte, ocorrendo então muitas vezes festejos públicos de natureza laica e religiosa, e o rei informava as principais cidades do reino do feliz acontecimento. Naquela $4^{\text {a }}$ feira, dia 31 de Dezembro de 1504 , D. Maria deu à luz uma rapariga, que assim se juntava aos irmãos João (n.1502), filho primogénito dos monarcas e futuro rei de Portugal, e Isabel (n. 1503), que havia de ser rainha de Espanha e imperatriz da Alemanha. Embora a gravidez da jovem D. Maria tivesse decorrido sem história, o rei ordenou que, naquela delicada fase em que o parto se aproximava, se 
ocultasse à rainha a notícia da morte de sua mãe, Isabel a Católica, ocorrida a 26 de Novembro, pela comoção e dor que a notícia provocaria em D. Maria. A grande rainha morrera amargurada com o problema da sua sucessão ${ }^{1}$, mas confortada com os sacramentos e acompanhada do seu companheiro de uma vida, Fernando de Aragão, mas não dos seus filhos, mortos uns, como Isabel e João, ou ausentes, como Maria, Joana e Catarina². Só depois a corte de D. Manuel observou o rigoroso luto que a situação impunha, contrastando com o momento feliz que era o do nascimento saudável de mais um filho, consolidando a dinastia.

Nascia a infanta filha de poderosos reis. Estava então D. Manuel num momento alto do seu reinado ${ }^{3}$. Nascido em Alcochete, em 1469, o mais novo dos nove filhos do infante D. Fernando $(† 1470)$, duque de Viseu e de Beja, irmão de D. Afonso V, e de D. Beatriz (†1506), também ela neta de D. João I, as sucessivas mortes dos muitos que antes dele estavam próximos do trono fizeram com que sucedesse, no final de 1495, a seu primo e cunhado, D. João II (r. 1481-1495). D. Manuel chegava ainda solteiro ao trono, e a sua nova condição de monarca tornava urgente que casasse. A vontade do novo rei foi tomar por mulher a primogénita dos Reis Católicos, Isabel ${ }^{4}$, o que veio a acontecer. Em 1498, dado que João, príncipe das Astúrias, morreu pouco depois de casar, Isabel e Manuel foram, por um breve tempo, os herdeiros jurados de todos os reinos cristãos hispânicos. Isabel morreu ao dar à luz, em Saragoça, em Agosto desse ano, o príncipe D. Miguel. Os Reis Católicos insistiram com D. Manuel no sentido de o monarca tornar a casar, desta vez com a infanta D. Maria (n. 1482), que viera ao mundo depois da primogénita Isabel (1470-1498), do ardentemente esperado filho varão, o frágil João (1478-1497), e de Joana (1479-1555), de infeliz destino. Catarina, que veio a ser rainha de Inglaterra, nasceu em 1485, e foi a última filha de Fernando e Isabel. D. Manuel parece ter hesitado,

\footnotetext{
${ }^{1}$ FERNÁNDEZ ÁlVAREZ, M., 2002, 2003 a.

2 Idem, 2003, p. 450.

3 V. a biografia do monarca, da autoria de COSTA, J.P.O.e, 2005.

${ }^{4}$ Viúva do príncipe herdeiro português, filho único e herdeiro de D. João II e de D. Leonor, irmã de D. Manuel, que morreu em 1491 da queda de um cavalo. Regressara a Castela após enviuvar.
} 
mas quando o filho morreu a sua disposição mudou: a 24 de Agosto de 1500, D. Manuel casava, por procuração, com a infanta D. Maria, que entrou em Portugal pela vila de Moura. Daí, no meio de grandes festejos, partiram para Lisboa onde foram levados da Ribeira à Sé, acolhendo-se depois aos paços da Alcáçova 5 .

Se as circunstâncias acabaram por tornar a herança peninsular de D. Manuel num episódio fortuito e sem consequências políticas, noutros territórios e em horizontes distintos se fazia a sua glória: em poucos anos de reinado, D. Manuel juntara "o Oriente ao Ocidente" 6 , com a chegada de Vasco da Gama à Índia, em 1498, e o seu capitão Pedro Álvares Cabral aportava em Abril de 1500, do outro lado do Atlântico, às terras de Santa Cruz. Neste ano de 1500, D. Manuel acrescentava ao título que tinha de "Rei de Portugal e dos Algarves, d'Aquém e d'Além-Mar em África, senhor da Guiné", o título da "Conquista, Navegação e Comércio, de Etiópia, Arábia, Pérsia e Índia"7. No lugar de Belém, de onde havia partido, em 1497, a armada de Vasco da Gama, o monarca mandava edificar um mosteiro da ordem dos Jerónimos que integrava de forma explícita a celebração da chegada dos portugueses à Índia, empresa culminante do seu reinado. O Mosteiro surgia em clara ligação com o projecto imperial do "Venturoso", inaugurando um novo "lugar» em que monarquia e império emblematicamente se encontravam ${ }^{8}$.

A infanta, que nasceu franzina e delicada 9 , vinha ao mundo em Lisboa, num final de ano em que houvera "nestes Reinos grandes, e espantosos terramotos ${ }^{10}$, que com frequência se faziam sentir ${ }^{11}$. Lisboa, que a tradição mítica queria fundada por Ulisses e na tradição cristã tinha como santo

5 GÓIS, D. de, 1949, I, cap. 22-34; RESENDE G. de, 1991.

${ }^{6}$ MENESES, P. de 1964, p. 113.

7 GÓIS, D. de 1949, cap. 46, pp. 110-114; THOMAZ, L.F., 1990, indica a data de 25 de Julho de 1499.

${ }^{8}$ Ligação estabelecida por GÓIS, D, de, 1949, cap. 53, e 1955, cap. 75, e outros autores. ALVES, J. da F., 1991, pp. 47-56. Sobre o projecto imperial de D. Manuel, v. THOMAZ, L.F., 1990 e PEREIRA, P., 1995.

9 SABUGOSA, C. de, 1912, pp. 118-119.

10 GÓIS, D. de, 1949, cap. 82, p. 193. OSÓRIO, J., 2004, liv. III, p. 69.

11 DIAS, J.A., 2005. 
protector o mártir S. Vicente, era então uma cidade em profunda e rápida transformação, quer pela sua nova condição de empório comercial à escala do globo, que lhe conferia um rosto mais cosmopolita e exótico, quer pelas transformações urbanas que nela se operavam. Desde logo, no lugar de morada da realeza. Quando os reis D. Manuel e D. Maria, depois de casar, entraram em Lisboa, acolheram-se aos paços da Alcáçova, "que até àquele tempo foram o verdadeiro, e próprio aposento dos Reis destes reinos" e onde, ainda na década de 1490, o rei D. Manuel procedera a importantes obras ${ }^{12}$. Habitado, nas suas estadias em Lisboa, por todos os reis da época medieval, também por todos fora, ao longo dos tempos, reconstruído, acrescentado e modificado, de acordo com os diferentes gostos e necessidades práticas dos reis. Já para finais do século XVI, o secretário do núncio papal, cardeal Alexandrino, observava nos seus apontamentos que o paço não tinha "forma alguma de arquitectura, por ter sido feito aos poucos em diversas épocas"13. Aí nasceram o príncipe D. João, último monarca português a vir ao mundo no velho paço, a infanta Isabel e, a 31 de Dezembro de 1504, a terceira filha dos reis de Portugal.

Decorria nesse ano de 1504 a construção de um novo paço junto ao Tejo, ordenado por D. Manuel no início do século, e sob sua directa supervisão. Com esta decisão, o monarca fazia descer a morada régia do alto da colina para a zona ribeirinha da cidade, implantando-a e articulando-a com a Lisboa dos tráficos marítimos e da mercancia, no âmbito de um verdadeiro "programa", também político, de reestruturação urbana da primeira cidade do país ${ }^{14}$. Doravante, o "rei da pimenta" iria habitar não no velho e alcandorado paço medieval, mas em aposentos construídos sobre a Casa da Índia e armazéns, próximo do burburinho de uma cidade cosmopolita, junto do palpitar do quotidiano febril da Lisboa comercial e mercadora de então ${ }^{15}$. Em Outubro de 1504, Lunardo da Cà Masser, enviado da Sereníssima República de Veneza a Lisboa, foi recebido por D. Manuel no paço da Alcáçova. Suspeito de espionagem, foi preso, mas depois de solto viveu

\footnotetext{
12 GÓIS, D. de, 1949, cap. 46, p. 113. GOMES, R.C., 1998, p. 98.

13 MARQUES, A. H. de O., 1994, p. 101.

14 CARITA, H., 1999; SENOS, N., 2002.

15 SENOS, N., 2002, p. 70. GONÇALVES, I., 1996. MOITA, I., 1994.
} 
ainda em Portugal cerca de dois anos, anotando escrupulosamente muita e preciosa informação sobre o reino; no seu relato fazia referência às obras do palácio em construção junto do rio, considerando-o, com o seu olhar veneziano, "uma fábrica muito baixa, com escasso desenho, e pobre"16.

Em finais de Março de 1505, quando o primeiro vice-rei, D. Francisco de Almeida, partiu para a Índia, ainda D. Manuel habitava no "paço de cima", de onde "ia, e vinha cada dia estar nas casas dos armazéns"17; mas em Dezembro desse ano, a farsa Quem tem Farelos?, de Gil Vicente, foi já representada perante a corte no paço da Ribeira, embora o monarca aí não habitasse ainda de forma permanente ${ }^{18}$. Assim se configurava o abandono da alcáçova como morada régia, e o seu consequente e progressivo declínio, em favor de um novo lugar de residência dos monarcas e de uma nova centralidade política e administrativa na cidade de Lisboa.

A infanta vinha pois ao mundo num pequeno e periférico reino do ocidente peninsular alcandorado a império cosmopolita e comercial, inundado de súbitas e longínquas riquezas, filha de um poderoso e venturoso rei, e num tempo de profundas transformações, também sob o ponto de vista daquele que seriam os espaços físicos do seu horizonte de vida e do seu quotidiano. Nascida na Alcáçova, foi o paço da Ribeira o lugar privilegiado da sua morada em Lisboa enquanto infanta de Portugal - embora não único, já que a medieval itinerância que fazia com que monarcas e a corte demandassem outras paragens ao longo do ano se mantinha no século XVI. E assim, também outros lugares, como Sintra, "jardim/do paraíso terreal"19, Almeirim, terra de caça, e Évora, lugares de tão grande predilecção de D. Manuel, fariam parte do "património" da experiência e do horizonte de vida da nova infanta.

São omissos os informes, cronísticos ou outros, sobre as festividades ocorridas aquando do seu nascimento, que devem ter sido discretas em virtude do luto observado na corte por morte de Isabel a Católica. E, mesmo que não fosse hora de luto e os festejos ocorressem da forma habitual, os

\footnotetext{
16 Publicado por GODINHO, V.M., 1979, p. 77. Sobre as relações entre Veneza e Portugal no reinado manuelino, v. OLIVEIRA, J.T.M. de, 2000, pp.43-58 e docs. 1-53.

17 CORREIA, G. 1921, T.I, P. II, p. 529.

18 SENOS, N., 2002, p. 19 e pp. 51-54.

19 VICENTE, G., II, 1984, p. 286.
} 
cronistas eram sempre mais lacónicos no registo do nascimento das filhas do que dos filhos varões - o mesmo sucedera em 1503, aquando do nascimento da infanta Isabel, mas não em 1502, quando nasceu o infante João, primogénito e herdeiro do trono, cuja vinda ao mundo sabemos ter provocado festas no paço e na rua, um pouco por todo o reino. Na penumbra, e sem suscitar sequer o interesse das crónicas ou outros registos, permaneceram também as cerimónias de baptismo desta infanta. Podemos imaginar esse momento de tão grande relevância religiosa e simbólica apenas por analogia com os relatos que se referem ao baptismo do seu irmão mais velho, dois anos antes. A cerimónia do baptismo ocorria em geral a muito breve trecho, já que, se sobreviesse a morte estando já baptizada, a alma da criança ascenderia logo ao Céu. Estando então a decorrer as obras no paço da Ribeira, e habitando ainda a família real o paço de cima, a infanta recebeu as águas do baptismo cerca de oito a dez dias depois de nascer, na capela dos paços do castelo. Se tudo decorreu como com o príncipe, a "sala grande" dos paços encontrava-se armada com toldo e dossel, ostentando a "cadeira rica, maças e oficiais de armas", bem como a sala da "senhora infante", mãe do monarca, e o recebimento cerimonial foi feito diante da porta da dita sala, de onde o cortejo desceu pela escada até ao pátio da capela ${ }^{20}$.

A capela real, espaço de culto e lugar religioso mais importante do paço era da invocação de S. Miguel, de grande devoção e culto no Ocidente medieval, anjo custódio de Portugal que em 1504 teve devoção e procissão instituídas para todo o reino, a pedido de D. Manuel. Para além de Lisboa, várias das capelas instituídas pelos reis portugueses nas suas residências mais antigas em Santarém, Coimbra e Évora foram colocadas sob a invocação deste arcanjo, chefe da milícia celeste ${ }^{21}$. Quando ocorreu o baptizado da infanta já lá existiria a imagem do arcanjo S. Miguel expulsando Lúcifer, descrita em 1571 por João Baptista Venturino como “obra de mestre", e forrada de tapeçarias, mas não ainda uma que é descrita como representando "ao natural el-rei D. Manuel, rodeado do conselho dos grandes,

20 Cortes..., 2001, pp. 11-13. SOUSA, A.C. de, 1947, dedica um longo capítulo a D. Beatriz e sua descendência, mas sem qualquer informação relevante sobre a própria, pp.171-207.

21 ANDRADE, M.V.F. de, s/d, pp. 143-144; GOMES, R.C., 1995, p. 115; História Religiosa de Portugal, 2, 2000, pp. 621-625; GIORGI, R., 2002, pp. 276-280; SILVA, J.C.V. da, 2002, pp. 30-31. 
quando resolveu mandar conquistar as Índias" ${ }^{22}$, parte de uma monumental encomenda feita por D. Manuel c. 1510, para celebrar o descobrimento do caminho marítimo para a Índia 23 . Com a construção do paço na Ribeira, a capela real recebeu um novo orago, S. Tomé, o apóstolo das Índias ${ }^{24}$.

Pelo baptismo, que ao tempo implicava bem mais do que um parentesco simbólico, a criança entrava na igreja de Cristo e recebia nome. Esta escolha nunca era aleatória. Sendo sempre um assunto de família ${ }^{25}$, no caso da realeza transmitia linhagem e memórias dinásticas. Relembremos o nome do próprio rei D. Manuel - "Deus connosco" e a carga simbólica acrescida de que se revestiu quando ascendeu ao trono ${ }^{26}$; ao seu filho e herdeiro foi dado o nome de João, que antes dele fora de dois outros monarcas portugueses: o da "boa memória", fundador da dinastia de Avis, D. João I (r. 1385-1433), e D. João II, a quem D. Manuel sucedera. Nesta escolha renovavam-se, pois, as memórias da monarquia. Manuel, o pai, escolhera-o a Providência para reinar; João, o filho, nascia já destinado ao trono, e por isso a escolha do seu nome não recaiu no do avô paterno, mas no dos reis de nome João, selando a continuidade dinástica.

No caso de Isabel, a memória recolhida através do nome era o da avó materna, a rainha Isabel a Católica. Por sua vez, a terceira filha de D. Manuel e de D. Maria recebeu, pelo sacramento do baptismo, o nome de Beatriz, nome que, sendo comum na família real, como aliás Isabel, estabelecia uma ligação simbólica directa com a infanta D. Beatriz, sua avó paterna, mulher de forte personalidade e dona de uma imensa fortuna ${ }^{27}$. Nos casos das duas infantas, mas não do herdeiro do trono, observara-se, pois, na escolha do nome, aquele que era o hábito generalizado, nas famílias aristocráticas, desde a Idade Média, de atribuir aos filhos mais velhos o nome dos avós ${ }^{28}$.

22 HERCULANO A., s/d, 88.

${ }^{23}$ FLOR, P., 2010, pp. 259-260. A tapeçaria foi encomendada vivendo já a família real no paço da Ribeira, mas de acordo com Venturino, encontrava-se, reinando D. Sebastião, no velho paço da Alcáçova, da predilecção do jovem monarca.

24 CARDOSO, J.M.P., 2004, p. 201.

25 GONÇALVES, I, 2010, p. 198.

26 V. GALVÃO, D., 1986, no "Prólogo" da Crónica de El rei D. Afonso Henriques.

27 Sobre a figura da infanta D. Beatriz, mãe de D. Manuel, v. MARTINS, M.O.S., 2009.

28 GONÇAVES, I., 2010, pp. 198-199. 
Não sabemos quem foi o padrinho da infanta Beatriz, quem a levou à pia baptismal, nem quem fez as tradicionais ofertas. Bastas vezes, esses eram também, como noutras ocasiões cerimoniais relevantes, momentos de fricção e de emulação entre membros das grandes casas aristocráticas, sempre ciosos de distinções e precedências, e com o próprio rei, como aconteceu na escolha do padrinho do infante D. João em 1502 quando, por vontade régia, a distinção coube a Pietro Pasqualigo, embaixador de Veneza, em representação do Doge, Leonardo Loredan. A presença do embaixador veneziano em Lisboa prendia-se com o auxílio que D. Manuel prestara a Veneza na luta contra o Turco, quando, a pedido do Doge, enviou em Junho de 1501 para o Mediterrâneo uma armada de trinta naus, 3500 homens e grande quantidade de artilharia, comandada por D. João de Meneses, $1^{\circ}$ conde de Tarouca. A participação portuguesa no conflito acabou por ser militarmente pouco expressiva, mas o empenho de D. Manuel espelhava os interesses estratégicos e de propaganda ao enviar aquela expedição ao Mediterrâneo ${ }^{29}$. A presença de Pasqualigo prendia-se também com a recente chegada à Índia, e a expectativa que em Veneza causavam os rumores da concorrência portuguesa sobre as especiarias orientais. A escolha do enviado veneziano para padrinho do herdeiro do trono foi recebida com mal-estar em certos sectores da corte. Nascer filho ou filha de rei comportava um "peso" social e simbólico particular, com implicações que diziam respeito não só à própria criança mas também à corte e, até, aos seus equilíbrios internos, tensões e sensibilidades. Voltando ao baptizado da infanta, as suas madrinhas tal como sucedera com João, foram sem dúvida as mulheres de maior peso e importância na família real, a rainha D. Leonor, irmã do rei e viúva de D. João II e a quem em certa medida D. Manuel "devia" o trono, e a infanta D. Beatriz, mãe de D. Manuel, embora nenhuma fonte documental ou cronística o refira.

Observando uma tradição enraizada nas práticas da aristocracia e da realeza, cumprida por D. Maria desde que nascera o seu primeiro filho, no momento em que foi baptizada, estava já a infanta D. Beatriz confiada à

29 RESENDE, V., 2004, apesar de o rei insistir que a sua prioridade era a guerra em Marrocos. CHAMBERS, D.S., 2000, p. 29. 
criação de uma ama-de-leite ${ }^{30}$. Chamava-se a ama Inês Álvares, e era mulher de Sancho Tavares, que nesse ano de 1504 fora incumbido pelo rei de delicada missão na praça africana de Mazagão. Fora mãe havia pouco de uma filha, Tomêa, que assim se tornava irmã colaça de D. Beatriz. Terminada a criação ao peito, Inês Álvares permaneceu no paço e obteve o cargo de camareira da infanta. Havia de acompanhá-la em 1521 para Sabóia, já viúva, levando no séquito da infanta outra das suas filhas, Francisca, que acabou por casar em Itália ${ }^{31}$. Em 1521, o rei concedia licença a Inês Álvares para, a seu pedido, fazer erguer num pequeno terreno no termo da vila de Almada uma capela da sua devoção ${ }^{32}$. Na mesma conjuntura, o monarca, "havendo nós respeito à criação e serviço que Inês Álvares ama da Infante Dona Beatriz duquesa de Sabóia [...] the tem feitos e esperamos que ao diante fará", concedeu-lhe uma tença anual de 15 mil reais a partir de Janeiro de 1522, com a cláusula de poder passá-la, por seu falecimento, para Tomêa ${ }^{33}$. Inês Álvares foi uma das figuras constantes na vida da infanta e depois duquesa de Sabóia, até pelo menos 1525, ano em que ainda vivia.

Nos primeiros anos de vida, o horizonte de sociabilidade de Beatriz, foi, como era habitual, um horizonte predominantemente feminino, na casa da rainha, entre a mãe, amas e aias, que velavam pelo seu bem-estar e o dos seus irmãos e tinham a seu cargo os cuidados quotidianos de higiene e alimentação. Era um ambiente protegido, também sob o ponto de vista das crenças e das devoções, sendo prática corrente as crianças usarem escapulários, bentinhos, amuletos e relíquias de santos ao pescoço, para as proteger e para sobre elas fazer recair a misericórdia e a protecção divinas ${ }^{34}$. Foi neste ambiente que Beatriz foi crescendo e vendo nascer, com uma continuada cadência, os irmãos mais novos: Luís (1506), Fernando (1507), Afonso (1509), Maria (1511), Henrique (1512), Duarte (1515) e António (1516). Percebemos agora melhor como a casa da rainha D. Maria esteve, em permanência e até à sua morte, em 1517, habitada por comadres,

\footnotetext{
30 BUESCU, A.I., 2010, pp. 16-19.

31 VITERBO, F. de S., 1914, pp. 54-56.

32 IAN/TT, CDM, liv. 35, fol. 88, de 8 de Fevereiro de 1521.

33 IAN/TT, CDM, liv. 18, fol. 93, de 22 de Julho de 1521.

34 JUNCEDA AVELLO, E., 1995, p. 29.
} 
criadas, escravas ${ }^{35}$ e amas-de-leite que se ocupavam das crianças que iam nascendo com regularidade impressionante, mas não invulgar.

Dos nove irmãos de Beatriz, seis eram rapazes e duas raparigas, mas a infanta Maria, nascida em 1511, morreu bebé ainda, em 1513, e o infante António com menos de dois meses de vida ${ }^{36}$. Desta forma, apenas Beatriz e Isabel, que faziam pouco mais um ano de diferença de idade, cresceram sempre juntas, o que também ajuda a compreender os particulares e estreitos laços de afecto e convívio entre as duas irmãs. Na verdade, por volta dos três anos de idade, uma mudança fundamental se operava no quotidiano das crianças, emergindo aqui a primeira grande diferenciação decorrente do sexo: as raparigas permaneciam a tempo inteiro na casa da rainha; os infantes, continuando entregues a uma ama, passavam a contar com os cuidados de mestres para começarem a familiarizar-se com alguns exercícios adequados ao seu nível etário, e considerados próprios do seu sexo e da sua condição, até deixarem, em definitivo, a casa da rainha. Sabe-se, no entanto, que no caso da rainha D. Maria houve sempre uma grande proximidade com os filhos, mesmo quando mais crescidos, como sucedeu com o príncipe herdeiro que se criou na casa da rainha "todo o tempo que ela foi viva”. Esta questão liga-se certamente também à decisão de D. Manuel em não dar aio aos filhos, rompendo com antiga tradição aristocrática e da realeza ${ }^{37}$. Os infantes Luís, Afonso e Henrique foram crismados, e em 1516 Afonso ordenado clérigo, "na sala da rainha, sendo elRei seu pai a isso presente"38.

As figuras mais próximas de Beatriz eram portanto a sua ama, depois camareira, entre os seus irmãos, Isabel, embora tivesse também uma relação próxima com todos os outros e, naturalmente, a mãe. Num círculo mais amplo, também a rainha velha, D. Leonor, mostrava pelas sobrinhas profundo

35 A 1 de Junho de 1515 um alvará de D. Manuel ordenava a entrega de 8000 a Marinha Gonçalves, ama do infante D. Luís, para a compra de uma escrava para seu serviço. IAN/TT, P. I, mç., 18, doc. 2. V. ainda As Gavetas da Torre do Tombo, vol. VI, 1967, XVI, 2-1, p.107.

36 Irmãos do casamento de D. Manuel com D. Maria; do enlace com Isabel de Castela nasceu Miguel da Paz (1498-1500); do terceiro casamento, Carlos (1520-1521), e Maria (1521-1577), poucos meses antes da partida de D. Beatriz para Sabóia.

37 ANDRADA, F. de, 1976 , cap. 5.

38 Relações..., 1937, pp. 200-201. CORREIA, G., 1992, p. 143. GÓIS, D. de, 1953, cap. 42. 
afecto $^{39}$. Quer o cronista Damião de Góis (†1574), que conheceu D. Maria do paço, quer o humanista D. Jerónimo Osório (†1580), descrevem a rainha como correspondendo em tudo aos padrões do tempo, e ao papel social dominante das mulheres para lá da sua posição social - o casamento, a procriação e o governo da casa: a rainha era recatada, discreta, em tudo fiel ao marido, cosia, fiava e bordava com as suas damas, cuidava e repreendia os filhos, não se intrometendo, escreve Osório expressamente, nos assuntos de Estado ${ }^{40}$. O cronista Gaspar Correia dá, contudo, uma imagem diversa da rainha D. Maria, mostrando-a como uma mulher dotada de luz própria, discernimento e razão política, interferindo no quadro das relações ibéricas, assistindo e participando de forma activa nos destinos da política portuguesa na Índia, carteando-se com Afonso de Albuquerque, envolvendo-se na actividade diplomática com a Santa Sé no âmbito do sonho imperial manuelino ${ }^{41}$. Retrato bem diferente do traçado quer por Góis quer por Osório, e de que divisaremos um traço importante relativo às suas filhas no testamento que deixou.

Foi portanto na casa da rainha que Beatriz foi crescendo e adquirindo os saberes que, também por sexo e condição, lhe cabiam a ela e a sua irmã Isabel. Nos primeiros meses de vida, a roca era o brinquedo associado à mais tenra infância e que, no caso da aristocracia e da realeza, era fabricada com materiais preciosos. Beatriz teve também, desde os primeiros meses de vida, a sua roca, tal como acontecia com os irmãos e irmãs que iam nascendo. Depois, na infância, as duas infantas entretinham-se sobretudo com brincadeiras consideradas próprias para as meninas, imitando o quotidiano da vida doméstica, brincando com colheres de pau e outros utensílios para a cozinha, bonecas, por vezes de cera, e outras figurinhas e miniaturas, pondo colares ao pescoço e enfeitando-se $\mathrm{e}^{42}$, o que sucedia independentemente da posição ocupada na escala social. Mas havia também

39 SOUSA, I.C. de, 2002, p. 132.

40 GÓIS, D. de, IV, 1955, cap. 19. OSÓRIO, J., 2004, liv. XI, p. 233.V. FERNANDES, M. de L. C., 1995, cap. 3, pp. 101-142 e idem, 2004.

41 PELÚCIA, A., 2004, pp. 291-293. A 13 de Outubro de 1505, a rainha escrevia uma instrução ao seu embaixador em Roma, a propósito de uma eventual aliança dos príncipes cristãos contra os muçulmanos. IAN/TT, CC, I, mç 5, doc. 50.

42 MANSON, M., 2002, pp. 51-95. SÁ, I. dos G., 2007, p 24. 
que adquirir um conjunto de comportamentos - no comer, no beber, no falar e no vestir - e de saberes próprios de quem havia de cuidar dos filhos, governar e saber manter mais tarde a sua casa.

Já Las Siete Partidas de Afonso X de Leão e Castela, (†1284), capital texto jurídico medievo, responsabilizavam directamente as rainhas, mães de suas filhas, na aquisição desses saberes e desses comportamentos virtuosos - afinal, eram muitos os saberes e "segredos" domésticos que se transmitiam e legavam de mãe para filha, tanto nos meios mais humildes como na realeza ${ }^{43}$. Fiar, coser e bordar, tarefas cultivadas e praticadas por todas as mulheres da aristocracia, foram actividades que Beatriz e Isabel também partilharam com a mãe e as suas damas. As primeiras letras e as primícias da doutrina cristã deverá tê-las aprendido Beatriz com o velho capelão do rei seu pai, Álvaro Rodrigues, que também ensinou D. João a ler, com recurso a silabários e cartilhas, e depois dele Isabel, que quando casou o levou consigo como deão da sua capela. Havia ainda que adquirir e interiorizar outras práticas: infantas e infantes tinham de aprender a dançar, a arte da conversação, o saber estar e como conduzir-se em cerimónias públicas da corte, no que eram industriadas quer pelas aias, camareiras, damas, por vezes por mestres leigos, quer, no caso dos rapazes, pelos seus mestres. O mestre de música dos infantes bem como de Isabel e Beatriz foi talvez um músico chamado Durão ${ }^{44}$. Finalmente, nesse processo de aprendizagem e crescimento tinham um lugar central a piedade e a devoção cristãs. Inculcadas pela prática quotidiana e pela participação em ofícios litúrgicos na capela da rainha 45 ou, a partir de certa idade, nas cerimónias de baptismo dos irmãos, a interiorização dos preceitos religiosos completavam-se na corte régia a partir da leitura de livros de horas e de devoção, do ler ou do ouvir ler episódios da vidas de santos, sermonários e tratados morais e de edificação, que a rainha possuía na sua câmara.

Das janelas, balcões e galerias de um paço agora situado no coração do pulsar urbano, junto ao Tejo, podiam também as jovens Beatriz e Isabel

\footnotetext{
43 AFONSO X, 1807, I, tít. VII, lei 11.

44 VASCONCELOS, C.M. de, 1949, p. 402.

45 Por alvará de 6 de Novembro de 1514, o rei ordenava que se dessem 14000 reis à rainha para sedas para a sua capela. IAN/TT, CC., P. I, mç. 16, doc. 103.
} 
observar o vaivém de gentes e mercadorias, o bulício, e o movimento da cidade, a chegada e a partida das naus, ou as "alimárias" que chegavam de terras distantes, como os imponentes elefantes de D. Manuel, cujo primeiro exemplar chegou a Lisboa em 1506, sendo instalados nas cavalariças do paço dos Estaus, no Rossio, com direito a guardadores próprios ${ }^{46}$. Símbolo de um império que havia sido dos Antigos mas que agora se jogava a uma escala geográfica nunca vista, o elefante chegara a terras da Cristandade, e o rei D. Manuel, o "[...] o primeiro Rei cristão da Europa a que vieram Elefantes da Índia". Orgulhoso "senhor da Conquista, Navegação e Comércio da Etiópia, Arábia, Pérsia e Índia”, comprazia-se em percorrer com frequência as ruas da Lisboa precedido de quatro ou cinco daqueles imponentes animais, para assombro e admiração das gentes ${ }^{47}$. Não podia o elefante faltar na grandiosa embaixada do "Venturoso" à Roma do papa Leão X em 1514, embaixada que alcançou ressonância europeia ${ }^{48}$, cimentou o prestígio do rei português na Europa e ecoou também em Lisboa e na corte de D. Manuel, que agraciou o embaixador Tristão da Cunha, no seu regresso, com uma importante tença ${ }^{49}$.

O dia 3 de Junho de $1515^{50}$, dia da Santíssima Trindade, a ninguém passou despercebido em Lisboa, tendo reis e infantes, bem como a corte e muito povo assistido a uma inédita encenação pública. Apenas cerca de quinze dias antes, a 20 de Maio, chegara a Lisboa, a bordo de uma nau proveniente da Índia, um animal nunca visto na Cristandade: tratava-se de um rinoceronte, oferecido pelo rei de Cambaia a Afonso de Albuquerque, que de imediato enviou a "bicha monstruosa" ao rei de Portugal51. A "bicha"

46 V. o alvará de 24 de Março de 1515, em que o rei manda dar vestiaria "aos mestres dos elefantes". IAN/TT, P. I, CC., mç. 17, doc. 98. A 3 de Junho de 1517, novo alvará régio para se dar vestiaria a "Pedro e Tomé, servidores dos elefantes". IAN/TT, CC., P.I, mç. 22, doc. 3.

47 GÓIS, D. de, IV, 1955, cap. 84.

48 GÓIS, D. de, III, 1954, caps. 55-57. O cap. 57 inclui a tradução de uma carta do cardeal Alberto Carpi ao imperador Maximiliano I ( $†$ 1519) descrevendo as sumptuosidades da embaixada. Republicado a partir de Góis por SOUSA, 1947a, pp. 266-269. V. ainda COSTA, J.P.O. e, 2005, pp. 164-165.

49 De 250 mil reais, pelos serviços prestados ao rei na embaixada ao papa. IAN/TT, CDM, liv. 24, fol. 31 .

50 Góis escreve, por lapso, que o episódio teve lugar em 1517, e não em 1515.GÓIS, IV, 1955, cap. 18.

51 COSTA, A F. da, 1937, pp. 9-10. 
provocou curiosidade e comoção em Lisboa. Desde a Antiguidade que elefantes e rinocerontes eram considerados inimigos mortais. E assim, quis D. Manuel "ver por experiência a força, \& manhas que cada uma delas tinha em se defender, \& cometer a outra”. Desta forma, um jovem elefante asiático e o rinoceronte recém-chegado foram postos num "terreiro cerrado", diante da antiga Casa da Contratação da Índia e da Guiné, ao paço da Ribeira, para em combate à maneira dos "Romãos" se ver qual das duas "bravíssimas, \& espantosas alimárias" sairia vencedora.

Esta encenação evidenciava, de novo, o poder de um rei que se jogava à escala do mundo, e a sua potencial dimensão de instrumento político seria, uma vez mais, habilmente utilizada por D. Manuel. Na verdade, tratou o monarca de, por seu turno, oferecer a "rinocerota" ao papa, juntamente com outros sumptuosos presentes ${ }^{52}$. A nau, capitaneada por João de Pina, saiu de Lisboa em Dezembro desse ano, despertando a curiosidade na Europa. O rei Francisco I de França fez questão de ver o animal quando o barco aportou a Marselha. Mas na costa de Génova a tormenta foi tal que, além da perda da preciosa carga, o rinoceronte morreu, sendo-lhe retirada a pele, empalhado e assim oferecido ao papa Leão $\mathrm{X}^{53}$. Mesmo morto e empalhado provocara admiração em Roma, sendo "cousa tão nova nestas partes nunca vista e quase não achada nos livros", como escrevia o embaixador D. Miguel da Silva ao monarca, em Agosto de $1516^{54}$.

Era, pois, este o ambiente que se vivia na corte manuelina, nos anos de infância da infanta Beatriz. Sabe-se que a infanta esteve presente quando se representou na corte, em ambiente de grande expectativa e tensão guerreira, a Exortação da Guerra de Gil Vicente, em 1513, antes da partida de D. Jaime, duque de Bragança, para a conquista de Azamor no norte de África ${ }^{55}$. Desde muito jovens sabiam bem, Isabel e Beatriz, de quem eram filhas e netas. Certamente nessa consciência dinástica e na opulência paterna

52 Incluindo peças de ourivesaria. V. ordem do rei ao ourives João de Pina, de Outubro de 1515. IAN/TT, CC, P. I, mç. 19, doc. 2, e a inventariação de especiarias e ourivesaria nas Relações..., 1937, pp. 198-199.

53 GÓIS, D. de, IV, 1955, cap. 18. BEDINI, S., 1997.

54 IAN/TT, CC, P. I, mç. 20, doc. 84.

55 VASCONCELOS, C. M. de, p. 382. 
enraizava a simultânea reserva e altivez que alguns testemunhos insinuam e que, no caso de Beatriz, por vezes se mostrou com clareza, sendo já duquesa de Sabóia. O escritor francês Brantôme (n. 1535), que não a conheceu, referir-se-ia à fama de D. Beatriz falando da sua "arrogância e soberba da sua forma de estar, do modo como vestia e também da sua grande beleza" "56. A historiografia contemporânea acolhe essa imagem altiva de D. Beatriz, até por contraste com o duque seu marido ${ }^{57}$.

Aparentemente um momento tranquilo e de apogeu da monarquia, apesar dos dramáticos e sombrios acontecimentos de 19 de Abril 1506, domingo de Pascoela, em Lisboa, na ausência de D. Manuel, com a perseguição e matança de cristãos-novos, que o rei castigou com dureza ${ }^{58}$, aproximava-se um acontecimento que para sempre mudaria a vida dos filhos de D. Manuel. Pouco passava da meia-noite do dia 8 de Setembro de 1516 quando, nos paços da Ribeira, a rainha D. Maria dava à luz o infante D. António. A criança nasceu fraca e foi baptizada logo dois dias depois pelo arcebispo de Lisboa, morrendo no dia de Todos os Santos. O nascimento do décimo filho de D. Maria foi demorado e muito penoso, e deixou sequelas das quais a mulher de D. Manuel nunca se recompôs. Foi na sua câmara que o Auto da Barca do Inferno de Gil Vicente foi pela primeira vez representado, "para consolação" da rainha, "estando enferma do mal de que faleceu", o que veio a acontecer a 7 de Março de 151759. D. Maria, rainha de Portugal e infanta de Castela, como se intitulava no seu testamento, morreu com trinta e cinco anos de idade; dos dez filhos que gerara deixava órfãos oito - o mais velho, o príncipe herdeiro D. João, com quinze anos ainda não cumpridos, o mais novo, o infante D. Duarte, com apenas um ano e meio de idade.

56 FREIRE, A. B., 1920, p. 8. ClARETTA; g. 1863, pp.53-54.

57 "Mais determinada do que Carlos III [sic] é a mulher, Beatriz de Portugal, senhora de vontade própria e orgulhosa, bem consciente do seu estado [...]". OLIVA, G., 1998, p.166.

58 O rei encontrava-se então em Avis, proveniente de Abrantes e dirigindo-se para Beja, para visitar a mãe. O episódio, que teve o seu rastilho no mosteiro de $\mathrm{S}$. Domingos, é relatado por GÓIS, D. de, I, 1949, caps. 102-103. RESENDE, G. de, 1991b, p.357.V. COSTA, J.P.O. e, 2005, pp. 141-144. Os privilégios suprimidos por sentença régia à cidade de Lisboa só foram restabelecidos mais de dois anos depois. CDM, liv. 5, fol. 16, de 2 de Agosto de 1508.

59 VICENTE, G., I, p. 201. GÓIS D. de, IV, 1955, cap. 19; CORREIA, G., 1992, p. 124. 
Se a sua morte acarretou consequências políticas que, no contexto da política ibérica e europeia, conduziram ao terceiro casamento de D. Manuel, desta vez com Leonor (n.1498), irmã mais velha de Carlos V ${ }^{60}$, interessa-nos aqui um outro plano, sobretudo relacionado com os filhos da rainha, agora órfãos de mãe, todos eles em idades tão precoces. Para lá do golpe afectivo profundo e irreparável, no que diz respeito a Beatriz e Isabel, as únicas raparigas, o desaparecimento da mãe teve outras imediatas e directas consequências. Na verdade, a sua morte implicou alterações na orgânica da corte, com o desmantelamento da casa da rainha, a redistribuição dos cargos palatinos pelas casas dos filhos mais velhos 61 e a criação da casa da infanta D. Isabel ${ }^{62}$.

Esta e a sua casa passavam a ocupar um lugar central na corte, substituindo a condição de "chefe" do sector feminino, também no que dizia respeito às rendas, honras, servidores, mercês, e a documentação, logo a partir de 1517, comprova-o abundantemente. Refira-se por exemplo, em Maio de 1517 , a doação da cidade de Viseu e da Vila de Torres Vedras a D. Isabel ${ }^{63}$, que antes haviam pertencido a sua mãe ${ }^{64}$, as nomeações de D. Diogo Ortiz, bispo de Viseu e do conselho do rei, como seu capelão-mor ${ }^{65}$, de Jorge Pires como tesoureiro da capela ${ }^{66}$ ou de André Pires, escrivão da câmara do rei, como seu escrivão da Fazenda 67 . O secretário régio, António Carneiro, recebia em Junho do mesmo ano carta de mercê de secretário e chanceler de D. Isabel ${ }^{68}$. Além das ligações à casa do rei, a casa da infanta apresentava naturais continuidades com a da rainha, e a camareira-mor de D. Maria, D. Elvira de Mendonça passou, em Julho de 1517, à condição de

60 COSTA, J.P.O.e, 2005, pp. 243-245. BUESCU, A. I., 2008, pp. 73-87.

${ }^{61}$ Por exemplo, Nuno de Sousa, fidalgo da Casa real e vedor da rainha, foi nomeado trinchante do infante D. Luís. IAN/TT, CDM, liv. 44, fol. 33, de 14 de Outubro de 1518.

62 SILVA, J.R.E., 2010, pp. 108-162.

63 IAN/TT, CDM, liv. 10, fol. 94v, de 20 de Maio de 1517. V. ainda IAN/TT, CC, P. I, mç. 22, doc. 134 .

${ }^{64}$ RÊGO, R. de F., 1933.

65 IAN/TT, CDM, liv. 10, fol. 33, de 30 de Maio de 1517.

66 IAN/TT, CC. P. I, mç.22, doc. 122

${ }^{67}$ IAN/TT, CDM, liv. 10, fol.55v., de 15 de Maio de 1517.

68 IAN/TT, CC. P. I, mç. 22, doc. 14. 
camareira das infantas D. Isabel e D. Beatriz ${ }^{69}$, bem como várias das suas damas cujo serviço transitou também para as infantas. Gaspar Correia afirma mesmo que "a casa toda inteira ficou com elas por morte da mãe"70.

Pouco depois da morte da rainha, D. Manuel ordenou a construção no paço da Ribeira de aposentos próprios para as infantas, as chamadas casas das infantas, não apenas um conjunto de câmaras mas, de acordo com a reconstituição de Nuno Senos, um verdadeiro conjunto residencial autónomo - paralelo ao do rei e infantes e do príncipe D. João. Aproveitando espaços pré-existentes, da própria casa da rainha, estes foram adaptados às necessidades de duas infantas quase mulheres, mandando o rei rasgar janelas com vistas sobre os jardins e o rio, e instalar lareiras numa das salas e nas duas câmaras de dormir. No piso inferior localizavam-se as casas das damas, em comunicação com os aposentos das infantas através de uma escada interior ${ }^{71}$.

Pouco sabemos do aspecto físico da infanta Beatriz, ao contrário do que sucedeu com Isabel, cuja beleza foi desde cedo objecto de explícita referência, e depois de imperatriz, amplamente fixada em tela, medalhas e estatuária ${ }^{72}$. De acordo com Jordan, o retrato de corte surge em Portugal apenas na segunda metade do século XVI ${ }^{73}$, embora não fosse improvável que no reinado de D. Manuel existissem retratos nas suas colecções, e que houvesse intercâmbio de retratos aquando dos contratos nupciais, como poderá ter sucedido aquando do casamento de D. Beatriz com o duque de Sabóia ${ }^{74}$. Em todo o caso, dada a sua ausência, torna-se necessário procurar na pintura de carácter devocional as escassas imagens da infanta D. Beatriz antes do seu casamento. Sabemos que, c. de 1515-16, D. Manuel ordenou no convento de Nossa Senhora da Serra, de fundação dominicana, próximo de Almeirim - terra de caça, onde os reis tinham paço que frequen-

\footnotetext{
69 IAN/TT, CDM, liv. 10, fol. 71v, de 30 de Maio de 1517.

70 CORREIA, G., 1992, p. 126.

${ }^{71}$ SENOS, N., 2002, pp. 79-80 e pp. 142-145.

72 MOURA, V.G., 1990. Não nos ocupamos dos retratos de D. Beatriz depois de duquesa de Sabóia.

73 JORDAN, A. 1994. V. ainda FLOR, P., 2010. No século XVIII, era ainda essa a memória da imperatriz, "a mais bela criatura daquele século". BA, cod. 50-IV-14, fol. 70.

${ }^{74}$ FLOR, P., 2010, p. 260-261.
} 
temente habitavam - a realização de um conjunto retabular que se calcula de grandes proporções, colocado na capela-mor, "em que se mandou retratar com a rainha Dona Maria; e depois todos seus filhos e filhas"75. Sobreviveram deste conjunto de tradição luso-flamenga, além da pintura Virgem com o Menino e dois Anjos ${ }^{76}$, as tábuas com os retratos de D. João e de D. Luís, mas não os restantes, entre eles o de D. Beatriz.

A primeira imagem em que surge D. Beatriz encontramo-la nos vitrais da capela-mor do Mosteiro da Batalha que representam, face a face, os respectivos doadores, D. Manuel e D. Maria, em oração. No vitral em que figura D. Manuel, junto do monarca encontram-se três crianças, a mais velha das quais retrata o príncipe D. João, e as mais pequenas os infantes Luís e Fernando. Em posição simétrica, junto da rainha D. Maria, também em atitude de oração, estão três figurinhas femininas, as suas filhas as infantas Isabel, Beatriz e Maria77. Os retratos régios destes vitrais (c. 1514) são muito próximos das estátuas em pedra dos monarcas no portal do Mosteiro dos Jerónimos (c. 1517), segundo Damião de Góis "tirados pelo natural"78. Podemos pois supor que também o retrato de D. Beatriz, represente de forma mais ou menos fidedigna o rosto e as feições da infanta, então com cerca de dez anos de idade, que no entanto mal se divisa, toucada como as irmãs e ajoelhada junto à mãe 79 .

Com maior destaque e pormenor encontramos representada a família real em oração a Jesus crucificado, na tela Fons Vitae. Numa organização hierárquica, orando, vemos o rei, à esquerda da imagem, com os filhos, e à direita D. Maria ${ }^{80}$, tendo a seu lado, em primeiro plano, a filha mais velha, Isabel, e em segundo Beatriz, com luxuosos vestidos e toucados em tudo idênticos, numa representação convencional e não retratística. Ao fundo, encontram-se representadas personalidades do Porto ligadas à Misericórdia

75 SOUSA, Fr. L. de, 1977 , p. 1140.

76 FLOR, P., 2010, p. 242.

77 Neste caso, será um retrato in absentia pois a infanta, nascida em 1511, falecera em 1513.

78 BARROS, C.V. da S. 1983, fig. 103-111, e p. 286.V. considerações de FLOR, P., 2010, pp. 249-250.

79 V. interpretação de FLOR, P., 2010, pp. 237-240.

${ }^{80}$ Embora a mais recente crítica sugira que possa tratar-se da $3^{\mathrm{a}}$ mulher de D. Manuel, o que não nos parece verosímil. V. FLOR, P. 2010, pp. 253-255. 
local $^{81}$. Figuração semelhante no tríptico da Virgem da Misericórdia do Funchal, em que a família de D. Manuel se acolhe à protecção da Virgem. No caso de mais esta pintura flamenga, cujo ascendente no reinado manuelino era indiscutível ${ }^{82}$, além do rei, estão representadas cinco figuras femininas, uma delas a rainha D. Maria, a outra talvez a rainha D. Leonor, fundadora das Misericórdias, e provavelmente as duas mais jovens correspondendo às figuras das infantas Isabel e Beatriz (esta encoberta) ${ }^{83}$.

Na Galleria Nazionali di Parma, de entre os onze retratos-miniatura que retratam figuras da corte portuguesa na primeira metade do século XVI, existe um retrato cuja identidade não foi até hoje estabelecida, de uma jovem que poderá corresponder a D. Beatriz. Não referido por Jordan na sua fundamental obra sobre o retrato de corte em Portugal, essa identificação foi há anos proposta por Giuseppe Bertini ${ }^{84}$, apresentando o retrato em causa inegáveis semelhanças físicas com os muitos retratos de Isabel $^{85}$. As descrições físicas da infanta noutros suportes também não abundam. No contexto das representações de Gil Vicente (†1536) na corte, há referências esparsas e não descritivas, mas simbólicas e alegóricas, à imagem física das infantas, como acontece na farsa Auto das Fadas ${ }^{86}$, a cuja representação no paço D. Beatriz assistiu, ainda criança. As fadas lançam sortes à rainha D. Maria, ao rei, ao príncipe D. João e às duas infantas, através da correspondência com deuses e planetas: ao rei cabe Júpiter, à rainha o Sol, ao príncipe Cupido, a Lua à infanta D. Isabel, “...Senhora Diana [que] tem do céu sua feitura e do Sol a formosura", Vénus a D. Beatriz: "A este planeta só olham todalas estrelas, porque é mais clara que elas"87.

${ }^{81}$ Fons Vitae, tela atribuída a Colijn de Coter, c. 1517, Porto, Santa Casa da Misericórdia.

82 CAETANO, J. de O., 2010, pp.200-204.

83 Jan Provost (?), Painel central do tríptico Virgem da Misericórdia (tríptico), c. 1514, Lisboa, MNAA.

${ }^{84}$ BERTINI, G., 1989. V. XVII ${ }^{a}$ Exposição..., 1983, pp. 60 e 159. Agradecemos à Galleria Nazionali di Parma e ao Dr. Luigi Ficacci, Soprintendente per il patrimonio storico, artístico ed etnoantropologico di Parma e Piacenza as informações fornecidas. V. SCHIANCHI, M.L. (dir.), 1998, pp. 205-210.

85 Não nos ocupamos dos retratos "italianos" de Beatriz, que incluem as medalhas em prata com o rosto, em perfil, da duquesa de Sabóia. LAMAS, A, 1916 e TRIGUEIROS, A.M., 2010.

86 Obra cuja datação é problemática. TEYSSIER, P., 1982, p. 95.

87 VICENTE, G., II, 1984, pp. 418-419. V. a leitura e integração desta farsa num universo cultural complexo, com raízes medievais em ALÇADA, J.N., 1999. V. ainda PALLA, M.J., 1996. 
Apenas no contexto da sua partida para Sabóia após o casamento por "palavras de presente" em Lisboa, a infanta-duquesa tem um lugar central na tragicomédia vicentina Cortes de Júpiter, representada nos paços da Ribeira perante a corte em 1521, mas novamente o registo, convencional, é o do poeta, e D. Beatriz surge como "deusa de Tróia”, "divina jóia”, "estrela entre as estrelas", "linda desposada", [...] muy hermosa a maravilla" 88 . Nem mesmo a poderosa e visual descrição de Garcia de Resende, o mais completo relato cronístico do casamento e partida da infanta para Sabóia, alguma vez alude à infanta sob o ponto de vista físico ${ }^{89}$. A beleza de Isabel parece "ofuscar" a imagem de Beatriz, como sucede no Auto das Fadas ou, num registo diferente, quando Gaspar Correia descreve a chegada do rei D. Manuel com sua terceira mulher, Leonor de Áustria, em Novembro de 1518, ao paço de Almeirim. As infantas, acompanhadas pelo duque de Bragança e pelos condes de Portalegre, de Tarouca e de Vimioso, e de todas as suas damas, esperavam a rainha "ao pé da escada da sala velha, que saía ao terreiro". A rainha, diz Gaspar Correia, "ficou pasmada da grande formosura da Infante D. Isabel", abraçando ambas e com ambas entrou no paço, levando-as "abraçadas até sua câmara [...]", onde se sentou e conversou com elas dando-lhes mostras de grande carinho 90 . Só os retratos e descrições italianas de Beatriz sublinham a sua beleza física. Em Agosto de 1523, numa ocasião em que os duques se dirigiam de Genebra para Sabóia, a duquesa era descrita como uma "jovem princesa de belíssimo rosto e eloquência real[...]"91.

Em 1518 terminava, no paço real de Sintra, residência de tão grande predilecção dos reis portugueses desde a Idade Média, e onde D. Manuel tão profundamente interveio ${ }^{92}$, a pintura da cúpula da Sala dos Brasões,

88 VICENTE, G., ibidem pp. 202-203 e 220.

89 RESENDE, G. de 1991a.

90 CORREIA, G. 1992, p. 126. É sabido o papel importante que mais tarde, já viúva de D. Manuel, D. Leonor teve junto de Carlos V para a sua decisão matrimonial, louvando as virtudes e a beleza da infanta D. Isabel. BUESCU, A.I., 2008, p. 189. CHAUNU, P. e ESCAMILLA, M., 2000, p. 681.

91 Cit. por CLARETTA, G., 1863, p. 51.

92 SILVA, J.C.V. da, 2002, pp. 200-247. 
"um dos ícones da política centralizadora manuelina"93. Considerada a mais importante sala heráldica europeia, o seu tecto pintado ostenta os brasões de setenta e duas famílias nobres do reino, por ordem de importância; a cúpula oitavada fecha com as armas de D. Manuel, encimadas por um dragão alado, rodeadas pelos brasões dos oito filhos que o rei teve de D. Maria, seis representando a sua descendência masculina, e dois brasões em lisonja, representando as armas das suas duas filhas 94 . Brasões em lisonja, partidos, pareciam aguardar o preenchimento da parte em branco através dos casamentos que lhes fossem destinados.

Sendo inegável a primazia dos filhos varões, a existência de filhas nas casas régias revelava-se um precioso instrumento no sempre complexo xadrez político e das alianças dinásticas. Em 1518, tinham Isabel quinze, e Beatriz catorze anos de idade, plenamente inseridas, pois, no que Bennassar chama o "mercado dos casamentos", verdadeira "bolsa de valores e de trocas95. Mas muito antes, como também sucedeu com filhas e filhos de D. Manuel, esses laços eram procurados, feitos e desfeitos ao sabor de conjunturas e interesses vários, numa volatilidade que só a sua condição de "arma" e instrumento político e diplomático pode fazer entender.

Já em Setembro de 1505, tinha o príncipe herdeiro 3 anos de idade, Pedro de Gouveia escrevia a D. Manuel sobre a possibilidade de contratar o casamento de D. João em Castela ${ }^{96}$, vindo mais tarde a estar praticamente concluído o seu enlace com a filha primogénita de Filipe o Belo e Joana a Louca, Leonor, que veio afinal a casar com D. Manuel. Por sua vez, o futuro Carlos V (n.1500), entre os dezoito meses de idade e os dezasseis anos e meio, chegou a estar prometido em casamento a três princesas francesas e a duas inglesas ${ }^{97}$, vindo a casar com a infanta Isabel de Portugal. Houve, até, compromissos matrimoniais selados, como sucedeu com D.

\footnotetext{
93 COSTA, J.P., 2005, p.97. A pintura do tecto da sala ocorreu entre 1515 e 1520 , mas em função da análise dos elementos heráldicos, é seguro afirmar que a cúpula foi pintada entre a viuvez de D. Manuel e o seu último casamento. FREIRE, A.B., I, 1973, pp. 22-23. SILVA, J.C.V. da, 2002, pp. 233-236.

94 Isto é, em losango. FREIRE, A.B., I, 1973, p. 33.

95 BENNASSAR, B., 2009, pp. 41-74.

96 IAN/TT, CC, P. I, mç.5, doc. 38, de 18 de Setembro de 1505.

97 CHAUNU, P. e ESCAMiLla, M., 2000, p. 677.
} 
Catarina (n.1507) que devido à conjuntura que levou à eleição imperial do irmão, casou, aos doze anos de idade, com João Frederico, sobrinho do eleitor do Saxe, contrato que veio a ser depois considerado inválido por ter sido obtido sob coacção. Veio D. Catarina a casar, em 1524, com D. João III, já rei de Portugal98.

No caso particular das infantas Isabel e Beatriz, já pelo menos desde 1512 que os seus destinos se gizavam no palco matrimonial. Nesse ano, João Mendes de Vasconcelos escrevia ao rei relatando a conversa havida com Pedro Núñez de Guzmán sobre o casamento do infante D. Fernando (n.1503), com uma das filhas do rei português99, hipótese que não teve sequência. Mas em 1516 surgiu uma proposta concreta, proveniente da Sabóia, em que Carlos II (1486-1553), que sucedeu a seu irmão Filiberto em 1504, pretendeu estabelecer uma aliança com o rei de Portugal através do seu casamento com a infanta D. Beatriz. Ascendera Carlos o Bom ao trono de Sabóia numa difícil conjuntura em que a ameaça francesa e o depauperamento financeiro tornavam frágil a situação do duque; e a sua decisão em procurar casamento com uma filha de D. Manuel tem de ser vista neste contexto preciso ${ }^{100}$.

O ducado de Sabóia-Piemonte, constituído por um importante conjunto de territórios fronteiriços entre a França, a Suíça e a Itália, tinha uma população que rondava um milhão de habitantes, e uma condição geo-política simultaneamente privilegiada e frágil. No século XV, as relações com a França, seladas por sucessivas alianças matrimoniais, eram muito estreitas. Francisco I, que subiu ao trono francês em 1515, era filho do duque de Angoulême e de uma filha do duque de Sabóia, Luísa. Desta forma, na segunda metade do século a influência francesa tornou-se preponderante, o que ajuda a explicar que o rei Carlos VIII (†1498), dando início em 1494 às campanhas de

98 BUESCU, A.I., 2007, pp. 105-106. Outros exemplos coevos em BARKER, R., s/d, pp.4-5. Agradecemos a Alexandre Monteiro o acesso à versão do texto corrigido pelo Autor. Luís (1523-36), então herdeiro dos duques de Sabóia, esteve prometido a Margarida de Valois com 3 anos de idade. BA, cod. 50-IV-12, fol. 12v.

99 IAN/TT, CC, P. I, mç.11, doc. 114, de 1 de Novembro de 1512.

100 "Em cujas núpcias esperava o Duque encontrar meios para melhorar a sua própria sorte [...]”. CLARETTA, G, 1863, p. 23. Já em 1519, o duque assinava uma declaração para o seu embaixador Honorato de Caix, afirmando pretender obter como dote do casamento a quantia de 300000 ducados e 100000 em jóias. Ibidem, p. 26, com a transcrição da declaração do duque. 
conquista em Itália, não tenha tido dificuldade em obter autorização de passagem para as suas tropas. Assim teve origem um longo conflito armado ao longo de toda a primeira metade do século XVI entre as grandes potências de então, a França e a Espanha. O palco, esse, era italiano ${ }^{101}$.

Antes de se voltar para Portugal, houve outros possíveis casamentos para Carlos II, sempre na órbita francesa. Em 1513, o marechal de França aconselhava Carlos II a casar, para não "deixar extinguir-se a vossa linhagem"102. Mas desejando, porventura, aliviar essa pressão, na altura em que, após a morte de Fernando o Católico em 1516, se tornou claro que o duque de Borgonha, e neto do imperador Maximiliano, Carlos (n.1500) cingiria também as coroas de Castela e Aragão, Carlos II de Sabóia, então com 30 anos de idade, pensou em alternativas. A "triagem" das possibilidades era simultaneamente política e conjuntural; era necessário analisar o "mercado das princesas". E, no longínquo e pacificado Portugal, reinava um enriquecido e poderoso rei que chegara à Índia, com uma casa cheia de filhos, entre os quais duas raparigas. Sendo certo que o rei de Portugal destinaria a filha mais velha a um casamento real, como veio a acontecer, a figura que se perfilou como hipótese foi a de Beatriz, a mais nova.

A embaixada com essa finalidade foi enviada pelo duque de Sabóia ainda em 1516, foi recebida por D. Manuel ${ }^{103}$. Mas o monarca, alegando, entre outras razões, a idade da infanta, não deu seguimento a esse pedido, pelo que os embaixadores regressaram a Sabóia "sem tomarem conclusão nenhuma”. Sabendo nós que era prática comum, na aristocracia e na realeza, os casamentos ocorrerem em idade precoce ${ }^{104}$, a negativa de D. Manuel em

101 RICE, E.F. e GRAFTON, A., 1994, pp. 110-145. JACQUART, J., 1994. La France..., 2001, pp. 1069-1070. SALMANN, J.- M., 2003, pp. 211-260. História da Europa, 2009, pp.77-107.

102 FORNASERI, G., 1957, p. 11. Agradecemos a Maria Luísa Cabral o acesso integral a este livro.

103 Em Lisboa, como afirma RESENDE, G. de, 1991a, p. 319. O rei permaneceu em Almeirim com a corte, entre Janeiro e Maio. De Junho a Dezembro esteve em Lisboa, com a pontual saída de Verão para Sintra, em Agosto. COSTA, J.P.O. e, 2005, p. 268. Mas no cod. quinhentista da BA, 50-V-21, fols. 201-204v, fala-se na recepção no paço de Almeirim e na oração do embaixador perante o rei.

104 "[...] o casamento de adolescentes de doze a quinze anos foi de uso corrente nas casas reais e ducais. Constitui um dos modos matrimoniais mais comuns, sobretudo no século xvi". BENNASSAR, B., 2009, p. 140. A idade dominante do casamento de infantas e princesas entre os séculos XV e XVII situava-se contudo entre os 16 e os 19 anos. Ibidem, Quadro 5, p. 274. 
casar a filha, então com doze anos, deixa entrever que, para lá do cálculo político, outras razões haveria para essa posição. E é aqui que entram a figura e a voz da rainha D. Maria. No seu testamento, redigido em Julho de 1516, a rainha recomendava a D. Manuel, quase exigia, que casasse as filhas fora do reino, mas com reis ou filhos de reis legítimos; "e quando isto não possa ser" - acrescentava D. Maria de forma liminar - "que as meta em freiras ainda que elas não queiram"105. No que respeitava à proposta saboiana era clara a oposição de D. Maria a um enlace que, embora com sentido estratégico, era visto como um casamento relativamente modesto, para a filha de um rei que de si queria dar imagem do mais poderoso da Cristandade ${ }^{106}$, e de uma rainha orgulhosa filha dos Reis Católicos. D. Maria mostrou decerto essa sua posição a D. Manuel, condicionando a decisão régia.

Plenamente inseridas no "mercado matrimonial", outras hipóteses se perfilaram para Isabel e, sobretudo, Beatriz, pois que para a mais velha já de há muito D. Manuel tinha uma ideia formada, como veremos. No final de 1519, proveniente da Baviera, a duquesa Cunegundes, viúva de Alberto IV († 1508), enviava missivas a D. Manuel, à rainha D. Leonor e a D. Leonor, a rainha velha, propondo o casamento do seu filho primogénito, que veio a ser o duque Guilherme IV $(† 1550)^{107}$ com uma das filhas em idade núbil - "nubilis etatis" - do rei D. Manuel ${ }^{108}$. Também neste caso o monarca não deu seguimento à proposta. Aliás, no seu testamento, lavrado a 7 de Abril de 1517, menos de um mês após a morte de D. Maria, D. Manuel recomendava ao seu herdeiro que protegesse e amparasse as infantas, procurando honrá-las com casamentos próprios do seu estado e condição.

É interessante notar como, neste ponto, transparecem no testamento do rei as preocupações que a falecida rainha D. Maria deixara bem expressas nas suas últimas vontades: casar as filhas fora do reino - embora aqui o monarca não falasse em reis ou filhos legítimos de reis, como fizera D. Maria - e, no caso de tal não ser possível, "encomendamos a elas que antes queiram servir a Nosso Senhor que os tais casamentos aceitar". Embora não

\footnotetext{
105 As Gavetas da Torre do Tombo, vol. VI, 1967, XVI, 2- 1, de 26 de Julho de 1516, pp. 108-109. 106 História de Portugal, 3, 1993 (texto de MAGALHÃES, J. R., p. 529), FREIRE, A. B., 1944, p. 137. 107 LOUDA J. e MACLAGAN, M., 1984, pp. 189-192.

108 As Gavetas da Torre do Tombo, vol. II, 1962, gav. X, 5-38 e 5-39, pp. 607-610.
} 
o dissesse, era certo que, na mente e na vontade do rei, o destino da filha mais velha estava traçado, mas não o de Beatriz, para a qual, aparentemente, o "episódio saboiano" parecia encerrado com a diplomática recusa de 1516, bem como a proposta bávara de 1519, à qual o rei não deu seguimento.

Quanto a D. Isabel, já desde pelo menos 1516 era indiscutível o desejo de D. Manuel e de D. Maria em casar a filha mais velha com o futuro Carlos V. Ainda em vida da rainha D. Maria, as intensas movimentações diplomáticas de D. Manuel após a morte de Fernando o Católico (†1516) envolviam negociações com vista a um duplo casamento, o de seu filho e herdeiro com Leonor de Áustria, e o da filha Isabel com Carlos de Gand; e se no que respeita ao primeiro enlace o monarca viúvo, num "golpe de teatro", casou em 1518 com a noiva que destinara para o filho, em 1526 a infanta D. Isabel casava com Carlos V, tornando-se rainha de Espanha e imperatriz da Alemanha. O codicilo ao testamento de 1517, datado de 11 de Dezembro de 1521, dois dias antes da morte do rei, deixava como encargo explícito ao seu sucessor "o cuidado de se acabar o casamento da infanta D. Isabel sua irmã com o imperador, no qual ele sabe quanto tenho até aqui trabalhado e quanto o desejo“109. D. João III cumpriu o desejo do pai, naquela que foi uma das "coroas de glória" dos seus primeiros anos de reinado, e também um profundo golpe nas finanças do reino em virtude do elevadíssimo dote de D. Isabel ${ }^{110}$.

E a vontade das infantas? É inverosímil pensar que não tivessem opinião própria sobre o seu destino como mulheres e como filhas de rei. Sobretudo após a morte da mãe e à medida que cresciam, a intimidade entre ambas passava também por sonhos e cogitações sobre os seus possíveis matrimónios. A partir de certo momento torna-se claro que, para além dos pais, também para a própria infanta D. Isabel se tratava de "Ó César, ó nada" 111 , desejo que pode ter-se tornado mais forte quando, depois, conviveu e desenvolveu uma relação de afecto com a madrasta, D. Leonor, irmã de Carlos V. Quanto a D. Beatriz, há indícios de que a infanta, escudada

\footnotetext{
109 As Gavetas da Torre do Tombo, vol. VI, XVI, 2-2, p. 134.

110 BUESCU, A.I., 2008, pp. 188-191.

111 SILVA, J.R.E., 2010, pp. 163-171.
} 
naquela que fora a opinião materna, terá mostrado resistência à decisão do pai, não sabemos se já em 1516, quando o rei acabou por recusar a "investida" dos embaixadores da Sabóia, era a infanta muito jovem, mas quando essa possibilidade se perfilou de novo, sem afinal nunca ter sido abandonada pelo duque, no ano de $1520^{112}$.

Neste ano, estando a corte em Évora, os condes de Tentúgal e do Vimioso recebiam, em Lisboa, nova embaixada enviada de Sabóia para retomar as negociações do matrimónio do duque de Sabóia com D. Beatriz, agora com dezasseis anos de idade. A embaixada, constituída pelos senhores de Broissy e de Chatel, secretário, munidos de instruções do duque datadas de 18 de Fevereiro, foi desta vez bem sucedida113. Sublinhe-se que a situação política mudara, na perspectiva de ambas as partes: agora, D. Manuel, pelo seu casamento com Leonor de Áustria, era cunhado do imperador Carlos $\mathrm{V}$, a quem prestara decisivo auxílio financeiro na guerra das Comunidades ${ }^{114}$, o que não podia deixar de ser uma situação conveniente a Carlos II, que aspirava a uma (impossível) neutralidade entre Francisco I e Carlos V; e para Portugal, tal aliança significava uma expansão dos interesses portugueses no "coração" da Europa"115.

Em Outubro de 1520, todos os filhos de D. Manuel recebiam a mercê do padrão de 449016 reais por ano, dos 8 contos da fazenda que ficara por falecimento da rainha D. Maria ${ }^{116}$. Talvez esta iniciativa do rei se articulasse, já, com a decisão tomada em relação a D. Beatriz, que não estaria sozinha na sua convicção de que casava abaixo do seu estado. Ao ocupar-se na Crónica de D. Manuel do casamento da infanta, Damião de Góis "anexa" um capítulo em que trata da antiguidade, prestígio e linhagem da casa de Sabóia, onde também o primeiro rei de Portugal casou. A razão fundamental

112 Ditos Portugueses..., 1997, n 669, p. 240.

113 ClARETTA, G., 1863, p. 26. RESENDE, G. de, 1991a, p. 319.

114 PÉREZ, J., 2001. Abundante documentação no IAN/TT sobre o tema. V. carta de Maffeo Rugel para o secretário António Carneiro, sobre a "grande obra" do empréstimo de D. Manuel a D. Carlos, CC. I. mç. 26, doc. 83, de 26 de Outubro de 1520, e carta (cópia) de D. Manuel ao condestável de Castela a estender por mais um ano o pagamento do empréstimo. CC, I, mç. 27, doc. 41, de 19 de Agosto de 1521.

115 COSTA, J.P.O. e, 2005, pp.251-253.

116 IAN/TT, CDM, liv. 36, fol. 85, 452-458. 
desse capítulo é clara: "no tempo em que se fez este casamento da Infante dona Beatriz com dom Carlos Duque de Saboia, \& ainda neste presente há [i] muitas pessoas que dizem que o Duque nem em geração, nem em estado tinha qualidades, porque the houvesse el Rei D. Emanuel de dar sua filha por mulher, posto que fosse filha segunda [..."117. Tal não impediu que D. Beatriz viesse a ser uma duquesa dedicada ao marido e adjuvante zelosa, activa e inteligente da sua governação nas situações difíceis, mesmo dramáticas, pelas quais passou o ducado enquanto viveu ${ }^{118}$.

Em Fevereiro de 1521, o monarca recebia no paço da Ribeira os embaixadores e procuradores do duque de Sabóia para concretizar o casamento de Carlos II com a infanta, entre os quais Claudio, senhor de Blaison, camareiro-mor do duque Carlos II, o barão de S. Germain e o doutor em leis Goffredo Pasero ${ }^{119}$. Agora, em 1521, tudo se iria consumar de modo muito rápido. A 18 de Março, o monarca encarregou Álvaro da Costa, seu camareiro e armador-mor, e Diogo Pacheco, doutor em leis e desembargador da Relação, de assentarem os termos do contrato de casamento com os embaixadores de Sabóia, portadores das instruções do duque. A 26 de Março, concluíam-se e eram assinadas as capitulações do enlace ${ }^{120}$, de que se congratulava o rei em carta ao duque a 3 de Abril ${ }^{121}$, e de imediato se iniciaram os preparativos para a partida da infanta, prevista para ter lugar no início do mês de Agosto.

A 7 de Abril, realizaram-se os esponsais. Nesse dia o príncipe D. João, acompanhado do infante D. Luís e de muitos nobres, foram ao encontro dos embaixadores, desta vez instalados nas casas de D. Simão de Meneses ${ }^{122}$ e não no paço real dos Estaus, o mais imponente edifício público de Lisboa antes da construção do Hospital Real de Todos os Santos, e onde normal-

117 GÓIS, D. de, IV, 1955, cap. 71.

118 Análise por CLARETTA, G., com base no epistolário da duquesa. V. tb FORNASERI, G, 1957.

119 CLARETTA, G, 1863, pp. 30-31, nomes grafados de forma diversa em FORNASERI, G., 1957, p. 11.

120 Contrato de casamento nas PHGCRP, 1948, pp. 18-27.Versão latina publicada por ClARETTA, G., 1863, doc. 5, pp. 140-152. Cópia ms. da versão latina na BPDVV, Miscelânea $\mathrm{n}^{\circ}$ XXXIX, fols. 39-44.

121 CLARETTA G., pp. 152-153.

122 BPDVV, Miscelânea, cit., fol. 44v. 
mente ficavam alojados embaixadores e outros visitantes ilustres ${ }^{123}$. Vinham a caminho acompanhados pelo marquês de Vila Real, pelo arcebispo de Lisboa e restante comitiva. O encontro deu-se junto da Sé, dirigindo-se então para o paço da Ribeira onde, na "sala grande dos paços, a qual estava toda armada de muito rica tapeçaria"124 tiveram lugar as cerimónias dos desposórios. Os reis D. Manuel e D. Leonor encontravam-se num grande e alto estrado alcatifado, com um dossel dourado e as cadeiras cobertas com um pano de ouro; por sua vez, os infantes Fernando, Afonso, Henrique e Duarte e as infantas Isabel e Beatriz, estavam todos no estrado, sentados em almofadas de brocado; de um lado e de outro da sala sentavam-se por sua vez as damas em alcatifas, e com elas muitos senhores e fidalgos. Uma grande quantidade de castiçais de prata de grandes dimensões com tochas iluminava a sala.

Foi neste cenário solene que teve lugar, ao cair da noite, o casamento da infanta D. Beatriz por palavras de presente, "com o Duque Carlos de Sabóia por meio de seus Procuradores, que para isso trouxeram suas suficientes e bastantes procurações" ${ }^{25}$. O acto nupcial foi oficiado pelo arcebispo de Lisboa, D. Martinho da Costa. Terminadas as cerimónias e o tradicional beija-mão, teve lugar um luzido serão que se prolongou noite dentro, em que o rei tomou a nova duquesa para uma primeira dança, abrindo o baile; depois, todos os presentes se entregaram aos prazeres da dança ${ }^{126}$. Em Junho, Carlos II recebia um breve de Leão X e a rosa de ouro, só atribuída pelo pontífice em ocasiões de particular importância $^{127}$. Em Julho, era publicado em Milão um Epithalamium celebrando a aliança entre a Sabóia e Portugal, de que foi produzida uma cópia especial em velino, destinada ao rei de Portugal ${ }^{128}$.

123 MARQUES, A.H. de O., 2004, p. 102. Mais tarde, nele veio a a funcionar o Tribunal do Santo Ofício.

124 BNP, cod. 886, p. 22. V. BPDVV, Misc. XXXIX, fols. 39-4

125 BNP, cod. 886, p.23.

126 RESENDE, G. de, 1991a, pp. 319-322. Utilizamos também a descrição dos embaixadores de Sabóia em carta datada de 10 de Abril. V. CLARETTA, G., 1863, pp.32-33.

127 CLARETTA, G., 1863, pp. 33-34.

128 BÜHLER, C.F., 1973. Existe exemplar desta rara edição na Biblioteca do Paço Ducal de Vila Viçosa, que pensamos ser única em Portugal. Agradecemos à Fundação da Casa de 
Poucos dias depois deste momento de festa, a 16 de Abril ${ }^{129}$, morria em Lisboa o infante D. Carlos (n.1520), primeiro filho de D. Manuel e da rainha D. Leonor, que a 8 de Junho dava à luz, no paço da Ribeira, o último dos filhos de D. Manuel, a infanta D. Maria. Foi a infanta baptizada nove dias depois pelo arcebispo de Lisboa. Foram padrinhos os dois embaixadores do duque de Sabóia e madrinhas as infantas D. Isabel e D. Beatriz ${ }^{130}$; houve trombetas e charamelas, mas as celebrações foram discretas, em virtude dos recentes falecimentos do infante e de D. Isabel, duquesa de Bragança.

Iniciados logo após a conclusão das capitulações matrimoniais, em fins de Março, os preparativos para a partida da agora duquesa de Sabóia prosseguiam, ordenando D. Manuel, a quem cabiam as despesas da viagem, uma imponente armada de dezoito velas, "todas muito bem equipadas, concertadas e artilhadas, afora a nau dos embaixadores que era grande, formosa, e bem artilhada"131. Seguiam também dois mil homens "com muita artilharia"132. A nada se poupou o monarca para prover a faustosa partida da primeira filha que casava, momento também privilegiado "para que pelas terras que passasse vissem sua muita grandeza e poder"133.

E precisamente por isso, mas também porque a viagem se fazia ao largo de cenários de risco e de guerra - o Norte de África muçulmano, o corso, a guerra das Comunidades em Castela, a permanente hostilidade entre Espanha e França ${ }^{134}$ - escolheu D. Manuel para nau capitânea a imponente nau Santa Catarina do Monte Sinai, "muito forte, muito formosa, muito veleira, e mui segura no mar"135, construída c. 1512 nos estaleiros de Cochim, na Índia, sob a direcção do italiano Silvestre Corgo, mas apenas

Bragança, e ao Dr. João Ruas, Director da Biblioteca, o acesso a esta obra e todas as facilidades concedidas. Também ClARETTA, G., 1863, se lhe refere com pormenor, pp. 40-44.

129 Relações..., 1937, p. 204. Dia 15, segundo outras fontes.

130 BNP, cod. 886, p. 25.

131 GÓIS, D. de, V, 1955, cap. 70. BARKER, R., s/d, p. 5, contabiliza entre 18 e 25 navios no total. No cod. 7638 da BNP, fol. 95, enumeram-se, para além da nau capitânea, 1 nau onde seguiu o arcebispo de Lisboa, outras 11 naus, 3 galeões, 12 caravelas, 4 galeões de menor tonelagem e 2 bergantins, num total de 34 navios. V. ainda BA, 50-V-21, fol. 237v.

132 BNP, cod. 7638, fol. 95.

133 CORREIA, G. 1992, p. 144.

134 BARKER, R., s/d, p. 2.

135 RESENDE. G. de, 1991 a, p. 329. 
lançada ao mar em 1517 136 . Com 38 metros de comprimento e 13 metros de boca, armada de mais de cem peças de artilharia, era um dos maiores e mais poderosos navios da época ${ }^{137}$. Este extraordinário navio é provavelmente o que surge numa tela considerada como uma das mais importantes representações de um navio de guerra antes do século XVII, mas cuja história é obscura ${ }^{138}$. Em todo o caso, a armada enviada por D. Manuel era composta por navios portugueses e saboianos e, embora se desconheça não só o autor da tela como o seu encomendante, há a hipótese de ter sido pintado para, ou a pedido da própria duquesa D. Beatriz ${ }^{139}$.

O dote de D. Beatriz, que recebera entretanto a legítima da mãe, aludida no contrato matrimonial ${ }^{140}$, ascendia à avultada quantia de 150000 cruzados, que incluía um enxoval de 50000 cruzados em jóias, pratas de serviço de mesa, câmara, capela e guarda-roupa, tapeçarias, paramentos, relicários e livros de devoção, um deles ostentando a divisa da rainha D. Maria ${ }^{141}$. D. Beatriz levava jóias sumptuosas, algumas as que lhe foram deixadas pela mãe em testamento, divididas com o herdeiro João e a irmã Isabel. A primeira peça referida ${ }^{142}$ é descrita como "duas fontes de prata douradas todas lavradas [...] com seus esmaltes de armas de Portugal e Sabóia”. Várias peças ostentavam também as armas de Portugal e Castela. Reflectindo uma tendência "escultórica" na joalharia da época, várias das peças ostentavam figuras, como guerreiros ou animais, sabendo-se que algumas delas foram executadas na Índia ${ }^{143}$. Também aqui a figura do elefante não faltava numa naveta de prata dourada, com uma cabeça de serpente na proa e um

136 IAN/TT, CC, I, mç.21, doc. 3, carta de António Real ao rei, de 3 de Janeiro de 1517.

137 Continuaria ao serviço da carreira da Índia, voltando ao Oriente com o novo vice-rei, Vasco da Gama, em 1524.VITERBO, F. de S., 1892, pp. 137 e 140.

138 Portuguese carracks off a rocky coast, óleo sobre tela, c. 1540, National Maritime Museum, Greenwich, Londres, Caird Collection. Atribuído a vários pintores, entre os quais o pintor régio Gregório Lopes, continua a suscitar especulações várias e contraditórias aos especialistas. BARKER, R., s/d., p. 10.

139 BARKER, R., s/d, p. 2, p. 10 e p.23, nota 25.

140 provas..., p. 22. ClareTTA, G., 1863, doc. V, p. 145. BPDVV, Misc. XXXIX, fol. $41 \mathrm{v}$.

141 CLARETTA, G, 1863, p. 47. V. enumeração e respectivo valor no contrato (cópia) do casamento, BPDVV, Misc. cit., fols. 41-41v.

142 Inventário publicado integralmente nas Provas...1948, pp. 27-81.

143 SILVA, N. V. e, 1995 , p.103. 
elefante na popa. Entre tantas outras peças, que não podemos enumerar mas faziam parte do dote habitual de uma princesa do seu tempo, D. Beatriz levava um tabuleiro de "xadrez de cristal guarnecido de prata dourada"144.

Com D. Beatriz viajavam, na Santa Catarina do Monte Sinai, D. Martinho de Castelo Branco, conde de Vila Nova de Portimão, capitão-mor e governador de toda a frota, a quem D. Manuel entregou a filha, acompanhado de muitos criados e parentes, filhos, genros e netos, na segunda nau da armada seguia o arcebispo de Lisboa, D. Martinho da Costa, que viria a falecer no torna-viagem, em Gibraltar ${ }^{145}$. Além da comitiva, D. Beatriz levava uma grande casa, com oficiais próprios, com destaque para o mordomo-mor, João Lopes de Sequeira, e o bispo de Targa como capelão-mor, moços de capela, guardas-damas, porteiros de maça, moços de estribeira, reposteiros, cozinheiros e homens de ofício, seis charamelas, três violas de arco, uma cítara, oito trombetas e seis tambores. No que respeita ao elemento feminino, entre as damas que a acompanhavam encontrava-se D. Leonor da Silva, que ia como camareira-mor, D. Mécia, filha de D. Dinis, irmão do duque de Bragança, D. Maria de Noronha, Inês de Melo, Francisca de Lacerda, e várias outras, além da sua ama Inês Álvares e sua filha Francisca, moças de câmara e guarda-roupa ${ }^{146}$. Muita gente, que era também preciso alimentar, e por isso seguiam também muitas provisões, que iam do pão às aves e à caça, incluindo 10 arrobas de açúcar que o rei mandou entregar, a 20 de Julho, a Martinho Vaz, guarda-reposte da duquesa ${ }^{147}$.

Tudo estava finalmente a postos para uma partida que o rei desejava se efectuasse a 25 de Julho, dia de Santiago. Mas a jovem duquesa adoeceu de febres, de que só se restabeleceu cerca de 2 semanas mais tarde. Domingo, dia 4 de Agosto, saíram do paço da Ribeira, pelas quatro horas da tarde, o rei D. Manuel, a rainha D. Leonor, o príncipe D. João, os infantes e infantas,

144 D. Manuel possuía um tabuleiro de xadrez cujas peças eram "elefantes e cavalos e homens". "Inventário....", 1904, p.413.

145 D. Diogo de Sousa, arcebispo de Braga, fora convidado pelo rei a acompanhar a infanta - BA, cod. 54-XIII-6, n 73, carta datada de Évora, de 7 de Dezembro de 1520 - mas essa distinção acabou por caber ao arcebispo de Lisboa.

146 Sobre a composição da casa da infanta, v. GÓIS D. de, op.cit., RESENDE, G. de, 1991 a, pp. 323-325, SÃO PAYO, C. de, 1930. NEVES, J.C., 1959.

147 IAN/TT, CC, I, mç. 27 , doc. 36. 
vestidos de gala, o rei à flamenga, o príncipe D. João à portuguesa, outros à saboiana. A duquesa-infanta seguia numa liteira com a rainha D. Leonor, a infanta D. Isabel numa mula, com guarnição e andilhas de chaparia de ouro. Garcia de Resende descreve de forma minuciosa e visual esta jornada que levou a família real e corte pela cidade, cheia de povo, da Tanoaria à Rua Nova, "que estava mui formosa cousa, toda armada de mui rica tapeçaria” e daí até à Sé, onde fizeram as suas orações. Encaminharam-se em seguida para as casas da rainha velha $\mathrm{D}$. Leonor, de quem a infanta D. Beatriz se despediu. Depois, pela Ribeira, a comitiva régia regressou ao paço onde, na grande sala ornada de ricas tapeçarias de ouro, dossel, alcatifas, cadeiras e almofadas de brocado, teve lugar um serão com música e dança.

Terminava o baile, já alta a noite; agora, pela mão de Gil Vicente, a Providência, "em figura de Princesa, com esfera e ceptro na mão", enviada por Deus a Júpiter, urgia com este nobre rei, senhor dos elementos, a que fizesse "cortes com solenidade": nelas devia ordenar que ventos, sol, lua e mares fossem propícios à viagem que havia de levar a "alta infante portuguesa, /duquesa pera Sabóia”. Convocado foi também Marte, deus da guerra, que assegurava perante o rei dos deuses a tranquilidade da viagem.

Num outro plano, inserindo-se num imaginário marinho, descrevia depois Gil Vicente o cortejo em que cónegos da Sé e vereadores da Câmara, estudantes e bacharéis, frades e ouvidores, juízes e regateiras, enfim, simbolicamente todo o reino, se transformariam num séquito de homens-peixes para acompanhar a partida da duquesa. Numa encenação carregada de referências mitológicas e astrológicas, talvez sublinhadas por algumas das tapeçarias que cobriam as paredes do grande aposento ${ }^{148}$ não faltava o "toque" burlesco e satírico que não atingia, no entanto, as personagens de sangue real: os infantes acompanhavam a duquesa, mas em natural majestade, e o príncipe herdeiro seria conduzido por cavalos-marinhos, num andor de ouro; a sua aparência era a de "um Alexandre Segundo"149. Tal como várias outras criações do seu autor, além da

\footnotetext{
148 RODRIGUES, M.I.R., 2004, pp. 40-42.

149 TEYSSIER, P., 1982, p. 138.
} 
construção alegórica, a tragicomédia Cortes de Júpiter evidenciava a plena integração da música na dramaturgia vicentina; quase no desfecho da peça, o "Romance"150 "Niña era la infanta"151 foi cantado "por planetas e sinos [sic] a quatro vozes"152.

O aparato dos festejos que se seguiram até à partida da frota foi extraordinário. No dia seguinte ao serão no paço, $2^{\text {a }}$ feira, dia 5 de Agosto, toda a família real, "com grandíssimo estado", acompanhada pelo duque de Bragança e a mais alta nobreza do reino, embaixadores, oficiais e toda a casa da infanta e de muitos músicos e instrumentos, atravessando a sala grande, situada no piso de cima do paço, desceram pela grande varanda e vieram ter a um cais ${ }^{153}$, "que estava dentro de água, tudo armado de mui rica tapeçaria, e o cais alcatifado”. Embarcaram num grande batel ornado de bandeiras e estandartes de damasco carmesim e branco, as cores heráldicas do rei. Em redor deste batel, e seguindo-o, todas as outras naus, galés, galeões e caravelas que compunham a armada ornamentados cada um com suas cores, soando a música das charamelas, trombetas e tambores; muitos outros navios, caravelas e batéis da cidade de Lisboa, embandeirados e enramados, seguiam também a nau onde se deslocava a família real. O povo de Lisboa apinhava-se nas janelas, a pé e a cavalo na Ribeira para assistir à partida da infanta-duquesa, que grossa artilharia assinalava, atroando os ares.

A nau Santa Catarina do Monte Sinai, ostentando bandeiras e velas de pano branco com as cruzes de Cristo, recebeu a comitiva através de uma grande ponte feita sobre barcas, armada de tapeçaria, onde todos cearam e estiveram até à noite. Retiraram-se então os reis e o príncipe D. João, que regressaram ao paço; a infanta $\mathrm{D}$. Isabel, os infantes, o conde de Vila Nova, os embaixadores e demais comitiva que seguiria em breve com D. Beatriz dormiram a bordo da nau, que é descrita quer no seu aparato exterior, quer

150 Um dos géneros poético-musicais mais difundidos na Península Ibérica desde finais da Idade Média.

151 BNP, Cancioneiro Musical, s/d (século Xvi). Reprodução parcial em Tesouros, 1992, p.270. 152 VICENTE, G., 1984, pp. 220-221. FERREIRA, M.P., 2008, pp. 60-62. V. ainda PESTANA, S., 1965 e RODRIGUES, M.I.R., 2004.

153 Cfr. SENOS N., 2002, pp. 62-63 e pp.92-93. 
nos seus luxuosos interiores, aposentos, câmaras - as da infanta "pintadas de ouro e forradas de brocados" 154 - escadas, despensas, cozinhas e ornamentos. A organização espacial dos aposentos destinados à infanta e suas damas e serviçais, descrita por Resende, recorda irresistivelmente os aposentos do paço da Ribeira: no andar de cima, as salas e câmaras da infanta, ornamentadas de tapeçarias de ouro, almofadas de brocado, veludos e alcatifas, e debaixo, com acesso através de escada, "o [aposentamento] das suas damas e mulheres, mais guardado que um encerrado mosteiro"155. No dia seguinte teve lugar um serão a bordo da nau, com a presença dos reis, infantes e membros da corte e séquito da infanta.

A partida aproximava-se; o dia seguinte, quarta-feira, 7 de Agosto, foi, segundo o cronista, um dia de lágrimas e saudade, em que as despedidas se faziam já definitivas. No dia 8, pela manhã, a nau Santa Catarina do Monte Sinai largou, e com ela todas as embarcações que compunham a armada que seguia para Nice, seguidas de uma multidão de barcos que da cidade queriam acompanhar a saída da infanta. Com D. Beatriz seguia o príncipe D. João e os infantes. Frente a Belém, deitaram âncora, sendo saudados por muita artilharia e música. No "baluarte grande, que está metido no mar"156 os reis e a infanta D. Isabel, sós, assistiam, "com muito grande saudade, muitos suspiros e lágrimas" à chegada da nau a Belém. O rei D. Manuel quis ver a infanta pela última vez; a rainha D. Leonor e a infanta D. Isabel quiseram acompanhá-lo; mas estando o mar "um pouco alevantado", apenas o rei, levado por um galeão, entrou na nau, onde também estavam o príncipe e os infantes. Foi talvez nesta ocasião que D. Manuel entregou a D. Beatriz umas instruções, datadas de 17 de Março, em que o rei dava à jovem duquesa conselhos a observar na sua vida pública e privada, e até de natureza política, exortando-a a ajudar a estabelecer a concórdia entre Carlos V e Francisco $\mathrm{I}^{157}$.

154 BNP, cod. 7638, no 50, fol. $94 \mathrm{v}$.

155 RESENDE, G. de, 1991 a, p. 330.

156 GÓIS, D. de, IV, 1955, cap. 81; SENOS, 2002, p. 62 e pp. 92-94.

157 VITERBO, F. de S., 1908, p. 11. Também ClARETTA, G., 1863 se refere a este documento de existente na Torre do Tombo. Em 1856, o visconde d'Alte, ministro português junto do rei Vitor Emanuel, fotografou o original português existente no Arquivo de Turim, fazendo várias cópias. Foi mais tarde publicado por Aníbal Fernandes Thomaz. Na BA existe uma cópia 
A despedida foi naturalmente emotiva: "el Rei nosso Senhor entrou, e foi ver a Senhora Infante sua filha, e esteve com ela um bom espaço só em sua câmara falando ambos, e acabado lhe deitou sua bênção, e com muita saudade, e grandíssimo amor se despediu dela, e assim o Príncipe nosso Senhor, e os senhores Infantes seus irmãos que com ela estavam todos, e se vieram à galé, e a senhora Infante Duquesa chegou a uma janela da nau da câmara onde estava, e desde aí viu a Rainha, a Infante sua irmã, e com muitas lágrimas, e soluços, e grandíssima saudade se despediu dela, e acabado, el Rei nosso Senhor com todos se veio para a Cidade, onde chegaram bem tarde".

Sexta-feira de manhã a nau que levava a infanta e todas as outras que a acompanhavam deram à vela, passando "pela torre e fortaleza de Restelo", que para assinalar a partida fez soar a artilharia. O tempo não permitiu contudo a partida, por falta de vento favorável ${ }^{158}$. No sábado pela manhã, dia de S. Lourenço, dez de Agosto de 1521, a armada levantava finalmente âncora. A viagem durou quarenta e nove dias, passando a frota pelas praças portuguesas de Tânger e Ceuta, onde foi saudada por caravelas e artilharia, e fez paragens em Málaga, Alicante - cidade comunera quase totalmente em ruínas, devido ao ataque pelas forças de Carlos V - e Marselha onde, em terra, membros da comitiva se depararam com calorosa recepção ${ }^{159}$. A frota chegou finalmente a Villefranche. Gaspar Correia refere a entrada da armada no porto e o primeiro encontro entre a duquesa e o duque, que terá ocorrido a bordo da nau capitânea ${ }^{160}$. D. Beatriz e o seu séquito desembarcaram a 3 de Outubro, já à noite causando, com o riquíssimo séquito que a seguia, profunda impressão pela riqueza feérica que ostentava. A duquesa seguia numa liteira de veludo e arminho, transportada por quatro fidalgos portugueses. Saudados pelo povo que, ao longo do

fotográfica de 1856, BA, cod. 51-VIII-1. Agradecemos à Dra . Conceição Geada a chamada de atenção para esta reprodução.

158 GÓIS, D. de, IV, 1955, cap. 70, situa a partida na 6 $6^{\mathrm{a}}$ feira, dia 9.

159 A fonte portuguesa que com maior minúcia descreve a viagem e a chegada a Nice é a crónica de CORREIA, G., 1992, pp. 148-150. Outra descrição detalhada na BA, cod. 50-V-21, fols. $236 \mathrm{v}-239$.

160 Importante discrepância com Claretta, que afirma ter ocorrido o primeiro encontro entre ambos mais tarde, já depois da entrada da duquesa em Nice, pp. 38-39. O retrato físico do duque feito por Gaspar Correia é pouco lisonjeiro, quase caricatural. CORREIA, G. 1992, p. 155. Mais sóbria a apreciação em BA, cod. 50-V-21, fol. 238. 
caminho até Nice clamava "Sabóia", "Sabóia, viva a nossa princesa", num percurso iluminado por candeias e tochas, fazendo-se ouvir a artilharia, a comitiva chegou ao paço ducal, onde era aguardada pelas irmãs do duque, Luísa de Valois, Filiberta de Sabóia, duquesa de Nemours, e várias outras damas, que acolheram a duquesa.

No dia seguinte, 1 de Outubro, foi celebrado o casamento religioso na igreja de S. Domingos em Nice ${ }^{161}$. Segundo Gaspar Correia, os únicos portugueses presentes na boda foram o conde de Vila Nova e o arcebispo de Lisboa. As festas nupciais prologaram-se por uma semana, incluindo um torneio em que participaram cavaleiros portugueses, espanhóis e italianos. Depois, o duque manifestou intenção de partir para o Piemonte, onde seriam recebidos em Turim com uma triunfal entrada. Foi neste contexto que ocorreram alguns desentendimentos e fricções entre portugueses e saboianos. Por ordem do duque, muitos membros da comitiva da duquesa foram impedidos de se lhe juntar, não seguindo com a duquesa para o Piemonte e vendo-se forçados a regressar ao reino. Pelo contrário, todas as damas seguiram a ama mas com reduzida pompa, o que provocou momentos de comoção e de lágrimas. Muitas delas haviam de casar em Itália.

Naqueles primeiros meses de casamento, D. Manuel foi sendo informado acerca da nova vida da duquesa por vários e frequentes correios. A 5 de Novembro, o licenciado Álvaro Anes informava o rei sobre o tratamento que o duque dava à infanta e sobre o modo com eram servidos à mesa ${ }^{162}$. Na mesma data, João Lopes de Sequeira dava conta ao monarca da boa disposição de D. Beatriz, que fora presenteada pelo duque com muitos vestidos e jóias, encontrando-se então instalados a 3 léguas de Turim, por causa da peste $^{163}$. A 4 de Dezembro de 1521 , entrava no Tejo a armada comandada pelo conde de Vila Nova, regressando da viagem que levara D. Beatriz até à Sabóia. Já D. Manuel, por informações que lhe haviam chegado por terra, sabia dos percalços e desentendimentos no recebimento da duquesa de Sabóia, novas que se sabe terem desagradado profundamente ao rei. Foi por estes

\footnotetext{
161 CLARETTA, G., 1863, p. 39.

162 IAN/TT, CC, I, mç. 27, doc. 65.

163 IAN/TT, CC, I, mç. 27, doc.66.
} 
dias, numa Lisboa em que os ares andavam carregados de pestilência que D. Manuel, estando com a sua corte no paço da Ribeira, adoeceu "de uma febre espécie de modorra, doença de que naquele tempo em Lisboa morria muita gente". Adoecendo no dia 4, a 11 ordenou o codicilo ao seu testamento e a 13 fechava os olhos ${ }^{164}$. Morria o "Venturoso" com cinquenta e dois anos de idade e vinte e seis de reinado, deixando viúva a sua terceira mulher, seis filhos varões e três filhas vivos, um império pelo mundo repartido, a sucessão do reino assegurada. Depois da entrada triunfal de D. Manuel e D. Leonor em Lisboa em Janeiro de $1521^{165}$, a partida de D. Beatriz para Sabóia foi o último grande acto público da sua existência. Gil Vicente prestava-lhe uma derradeira homenagem no Romance à morte de D. Manuel, e sublinhava a proximidade temporal e o contraste entre ambos os acontecimentos: "Oh, quem viu as alegrias/daquelas naves tão belas, /belas e poderosas velas, / agora há tão poucos dias/ para ir a Infante nelas!" 166 .

D. Beatriz recebeu com natural tristeza a notícia da morte do pai, ocorrida tão poucos meses depois de chegar a Sabóia, e o seu sentimento de orfandade tornou-se certamente mais agudo ainda pela distância. Nunca mais tornou a ver qualquer dos seus. Procurando obter vantagens para a causa saboiana junto do imperador, Beatriz de Sabóia tentou acompanhar o seu filho Luís (n.1523), quando este partiu, em 1533, "a criar-se com o Príncipe D. Filipe, seu primo" 167 , mas tal não aconteceu, assim se gorando o desejado reencontro com a sua irmã Isabel ${ }^{168}$; e a hipótese, que chegou a tomar forma, de ter o seu irmão D. Luís mais perto de si como duque de Milão, em 1535169, nunca se concretizou. Em1529, o rei instruiu o seu embaixador ao imperador, D. Pedro de Mascarenhas, que visitasse os duques ${ }^{170}$.

164 GÓIS, D. de IV, 1955, cap. 83. FREIRE A. B., 1944, p. 150.

165 BUESCU, A.I., 2008, pp. 94-101.

166 VICENTE, G., II, 1984, p. 627.

167 BA, cod. 50-IV-12, fol. 12

168 FORNASERI, G, 1957, pp. 36 e 43.

169 DESWARTE, S., 1991.

170 Com instruções expressas para veicular os pedidos que lhe fizessem junto de Carlos V. Relações..., 1937, pp. 68-69. V. ainda as cartas enviadas pelo rei aos duques de Sabóia, ibidem, pp. 72-73. Em instrução posterior, o rei desistia de mandar o embaixador a Sabóia, mas mantinha a ordem de defender os interesses do ducado junto do imperador. Ibidem, p. 79. 
Em 1532 enviou João Sepúlveda, fidalgo da sua casa, a visitar e saber notícias mais próximas e directas dos duques de Sabóia, seus filhos e seu estado $^{171}$, e em carta de 28 de Setembro de 1534 o rei falava já de futuras possíveis alianças matrimoniais para uma das filhas da irmã, com o duque de Bragança, D. Teodósio ${ }^{172}$. A duquesa continuou a cartear-se com os membros da sua família, com destaque para a imperatriz, que em 1536 reagia com comoção e amargura ao colapso do ducado de Sabóia perante a França e à morte do sobrinho ${ }^{173}$, e D. João III, que sempre procurou ter notícias de D. Beatriz e da sua família, e acautelar os interesses da irmã ${ }^{174}$. Manteve também D. Beatriz contacto regular ${ }^{175}$ com personagens destacadas da corte, como o secretário António Carneiro e com António de Ataíde, do conselho do rei e seu vedor da Fazenda, recomendando servidores seus e pedindo ajuda em tantos momentos de dificuldades financeiras ${ }^{176}$.

Em 1531, António de Ataíde foi enviado como embaixador de D. João III a França, no âmbito do delicado diferendo entre Portugal e a França acerca

${ }^{171}$ Instruções do rei em Relações..., 1937, pp. 126-131. Com diferenças, As Gavetas..., vol. X, XX, 6-38, pp. 486-492, e BNP, cod. 886, pp. 277-289. Sepúlveda foi informando o rei sobre os duques. IAN/TT, CC, I, mç. 49, doc. 86, 28 de Agosto de 1532, e mç.50, doc. 23, de 30 de Outubro de 1532.

172 BNP, cod. 10851, fols. 53-54. D. Teodósio (n.1510?) sucedera cerca de 2 anos antes na casa ducal a seu pai, $4^{\circ}$ duque de Bragança ( $\left.† 1532\right)$. Outros casamentos foram hipótese também em Itália, na casa Farnese. Carta de Hieronimo Capodiferro a Alessandro Farnese, de 25 de Agosto de 1539, e carta deste ao núncio, de 30 de Setembro do mesmo ano, La Correspondance..., 1980, doc. 127 e 128, pp. 381-392.

173 MAZARIO COLETO, M. del C., 1951, p. 151 e doc. LXXXVI: "De que recebi grande pena, pela [pena] que terá a Ilustríssima infante minha irmã, e o duque seu marido, pois devia bastar-lhes os trabalhos que passaram com a morte do filho [Luís, príncipe do Piemonte], sem verem perder e destruir agora todo o seu estado". Carta da imperatriz Isabel a Carlos V, de 25 de Março de 1536 (em cifra), p. 454. V. ainda doc. CXI, carta de 26 de Maio de 1538, em que a imperatriz intervém novamente em favor da Sabóia, "pela obrigação e amor que lhes tenho [...]", e doc. CXIV, de 25 de Julho de 1538, p. 523 e p. 533.

${ }^{174}$ IAN/TT, CC, I, mç. 29, doc.2, carta de D. João III, de 8 de Janeiro de 1523 , ordenando ao embaixador Luís da Silveira que falasse com o duque de Sabóia sobre o cumprimento do contrato de casamento; CC, I, mç. 32, doc. 103, de 30 de Agosto de 1525, carta da ama da duquesa Inês Álvares ao rei, dando-lhe conta da gravidez de D. Beatriz. Para um dos seus primeiros partos, D. João III fez chegar à corte de Sabóia uma comadre portuguesa. CLARETTA, G., 1863, p.113.

175 Mais alguns exemplos em VITERBO, F. de S. de, 1908, doc. V-IX.

176 IAN/TT, CC, I, mç.21. doc. 38, carta da duquesa agradecendo a António Carneiro o bom recebimento na corte do seu estribeiro-mor, de 16 de Fevereiro de 1527; IAN/TT, I, mç.18, doc. 80, carta ao rei pedindo-lhe que favorecesse a sua ama numa causa ou, em 4 de Setembro de 1525 , pedindo ao rei a mercê do hábito de Cristo e uma tença para o seu secretário. IAN/ TT, I, mç. 18 , doc. 81. 
do corso francês sobre as naus da Índia ${ }^{177}$. Nessa ocasião, D. Beatriz escreveu-lhe pedindo-lhe para a visitar, pois, como dizia, "sei que daqui a muito tempo não virá outro a que eu tanto folgue de dar conta de todas minhas cousas [...]"178. Em 1536, ano da invasão da Sabóia pelas tropas francesas, a duquesa recebia em Milão a visita do prior de S. Domingos, fr. Jorge Vogado $^{179}$. Em carta de 1 de Julho de 1537, o embaixador Francisco de Carvalho escrevia ao rei que a duquesa se encontrava muito debilitada, com febres persistentes ${ }^{180}$. Embora não aludisse ao estado, D. Beatriz encontrava-se nos primeiros meses de gravidez do que seria o seu último filho. A 18 de mesmo mês, o embaixador tornava a sublinhar o estado enfraquecido da duquesa ${ }^{181}$. Em mais momento de grave crise político-militar entre a França e o martirizado Piemonte, o embaixador informava o rei que D. Beatriz "desejava passar-se em Castela e o havia escrito ao imperador [...]"182. Carvalho veio, aliás, a ser uma das testemunhas quando a duquesa, em Novembro desse ano, fez redigir o seu testamento ${ }^{183}$.

D. Beatriz, que tantos filhos deu a Carlos II, teve uma dolorosa experiência como mãe, como sucedeu com tantas mulheres do seu tempo. Dos oito filhos que a duquesa de Sabóia deu à luz, sete morreram-lhe em vida, e de parto veio a morrer em Nice, a 8 de Janeiro de 1538, poucos dias depois de cumprir os 33 anos de idade, ao dar à luz o seu último filho, estando o duque ausente. Apenas sobreviveu o filho varão nascido em 1528, Emanuel Filiberto, príncipe do Piemonte após a morte de Luís, seu irmão mais velho, aos 13 anos de idade.

Quando Carlos II morreu em 1553, em Vercelli, o futuro do ducado era sombrio, com a Sabóia e o Piemonte ocupados pelos franceses e o único filho ao serviço do Império, a quem Carlos V, nesse mesmo ano, dava o cargo de governador da Flandres. De certa forma, triunfara a natural inclinação

\footnotetext{
177 FERREIRA, A.M.P, 1995. Várias instruções do rei nas Letters..., 1931.

178 Colecção de São Lourenço, I, 1973, doc. 30, carta de 5 de Setembro de 1531.

179 IAN/TT, CC, P. I, mç. 57, doc. 43

180 As Gavetas da Torre do Tombo, vol. IV, 1964, XV, 11-25, pp. 367-368.

181 Ibidem, carta de Francisco de Carvalho a D. João III, 18 de Julho de 1537, p. 369.

182 Ibidem, carta de Francisco de Carvalho a D. João III, de 1 de Julho, p. 368.

183 CLARETTA, G., 1863, pp. 100-104.
} 
"ibérica" de sua mãe, como com alguma crueza escreve Damião de Góis na sua Crónica ${ }^{184}$. Emanuel Filiberto subiu ao poder num Piemonte devastado, que conseguiu reconstruir, a pulso, no quadro de uma aliança estreita com a Espanha de Filipe II (1527-1598)185. Grande militar e estratega, o "Testa de Ferro" foi um dos heróis da batalha de Saint-Quentin, em 1557, ao lado das forças espanholas. A paz de Cateau-Cambrésis, assinada em 1559, selava a hegemonia espanhola no palco europeu, enquanto a França soçobrava, com a morte acidental do rei Henrique II, e internamente dilacerada pelas guerras de religião. Emanuel Filiberto recuperou a maior parte do ducado paterno e, com a sua governação, conseguiu refundar o Estado. Em 1571, participou, com as outras forças da Cristandade, na vitoriosa batalha de Lepanto contra os Turcos, pondo termo ao longo e continuado processo expansionista do império Otomano para Ocidente.

Para lá, naturalmente, do plano afectivo e de uma consciência e memória dinásticas que não podiam deixar de fazer parte da identidade de Emanuel Filiberto, parecia longínqua a relação do duque de Sabóia com a pátria da mãe. Mas a gravíssima crise dinástica portuguesa, aberta quando o rei D. Sebastião (n.1554) desapareceu, solteiro e sem sucessão, na expedição africana de Alcácer-Quibir, em $1578^{186}$, fez com que, depois da morte do seu efémero sucessor, o seu tio-avô cardeal D. Henrique, que morreu em 31 de Janeiro de 1580, a sucessão do reino fosse oficialmente disputada por vários pretendentes ${ }^{187}$. Foi neste contexto que também Emanuel Filiberto, neto por via materna de D. Manuel, surgiu como candidato ao trono de Portugal, efémero embora, pois veio a morrer aos 52 anos de idade, a 30 de Agosto desse mesmo ano de 1580, em Turim. E, no que respeitava à sua

184 GÓIS, D. de, 1955, cap. 70.

185 OLIVA, G., 1998, pp. 181-227.

186 V. a recente biografia do monarca da autoria de CRUZ, M.A.L., 2006.

187 Filipe II era neto de D. Manuel e filho de D. Isabel; D. António, filho bastardo do segundo filho varão de D. Manuel, o infante D. Luís; o duque de Sabóia, Emanuel Filiberto, neto de D. Manuel e filho de D. Beatriz, segunda filha de D. Manuel; o príncipe Rainúncio Farnese, filho da infanta D. Maria de Parma e neto do infante D. Duarte, irmão de D. João III; D. Catarina, duquesa de Bragança, filha do infante D. Duarte, e Catarina de Médicis, rainha-mãe de França, que alegava a sua pretensão remontando ao século xiII, ao casamento de D. Afonso III com Matilde de Bolonha, de quem se considerava descendente legítima. Os três mais fortes candidatos foram Filipe II, António, Prior do Crato, e Catarina de Bragança. 
relação a Espanha de Filipe II, essa candidatura era, a vários títulos, uma posição difícil de sustentar. Chegou, como todos os outros, ainda antes da morte de D. Henrique, a ter embaixador da sua causa em Lisboa, Carlos della Rovere, chegado a Lisboa a 20 de Abril de 1579188. Reinava em Lisboa um ambiente pesado de movimentações, crispação e intriga, também indisfarçável entre os vários embaixadores ${ }^{189}$. A poderosa "máquina" política, jurídica, diplomática, e depois do desaparecimento de D. Henrique, também militar, de Filipe II, encarregar-se-iam de afastar todos os outros candidatos, fazendo com que fosse ele, também neto de D. Manuel por via materna, a subir ao trono português, consumando a união ibérica.

Emanuel Filiberto morreu em 1580, e o episódio da sucessão portuguesa acabou por ser um breve e final parêntesis da sua vida. Mas ao fazer com que o nome do pai, Manuel, fosse parte do nome e da identidade do seu filho e herdeiro do ducado de Sabóia, D. Beatriz assegurou, simbolicamente, que esse laço nunca fosse quebrado, e o nome do "Venturoso", inaugurado com o sucessor de Carlos II no ducado de Sabóia perdurasse, cinco séculos mais tarde, na casa real italiana ${ }^{190}$.

\section{Fontes e estudos}

\section{Fontes manuscritas}

\section{Biblioteca da Ajuda (BA)}

cod. 50-IV-12, Ilustração da Arvore genealógica da sereníssima Casa de Bragança

cod. 50-IV-14, Epitome dos Reis e Familia Real

cod. 50-V-21, Miscelânea Histórica

cod. 50-V-26, Miscelânea

188 POLÓNIA, A., 2005, p. 204.

189 IAN/TT, I, mç. 111, doc. 78, de 5 de Janeiro de 1580.

190 D. Beatriz dera o nome de Manuel a outros dois filhos varões, nascidos em 1533 e 1534, que morreram na infância, facto bem significativo do desejo da duquesa em assegurar a continuidade simbólica da casa paterna na casa de Sabóia através desse elemento poderosamente identificador, o nome. 
cod. 51-VIII-1, Istruzione del Re di Portogallo Emanuelle a Beatrice Duchezza di Savoya in lingua portoghese... (cópia fotográfica do documento original no Arquivo de Turim)

54-XIII-6, no 73

\section{Biblioteca Nacional de Portugal (BNP)}

cod. 886

cod. 7638

cod. 10851

Instituto dos Arquivos Nacionais/Torre do Tombo (IAN/TT)

Chancelaria de D. Manuel

CDM, liv. 5, fol. 16

CDM, liv. 10, fol. 33

CDM, liv. 10, fol.55v

CDM, liv. 10, fol. $71 \mathrm{v}$

CDM, liv. 10, fol. 94

CDM, liv. 18, fol. 93

CDM, liv. 24, fol.31

CDM, liv. 35, fol. 88

CDM, liv. 36, fol. 85

CDM, liv. 44, fol. 33

\section{Corpo Cronológico}

CC, P.I, mç. 4, doc. 60

CC, P.I, mç. 5 , doc. 38

CC, P.I, mç. 5, doc. 47

CC, P.I, mç. 5, doc. 50

CC, P.I, mç. 5, doc. 93

CC, P.I, mç. 11, doc. 114

CC, P.I, mç. 16, doc. 103

CC, P.I, mç. 17 , doc. 98

CC, P.I, mç., 18, doc. 2

CC, P.I, mç. 18 , doc. 80

CC, P.I. mç. 18, doc. 81

CC, P.I, mç. 19, doc. 2

CC, P.I, mç. 20, doc. 84

CC, P.I, mç. 21, doc. 3

CC, P.I, mç. 21, doc. 38

CC, P.I, mç. 22. doc. 3 
CC, P.I, mç. 22, doc. 14

CC, P.I, mç. 22, doc. 122

CC, P.I, mç. 22, doc. 134

CC, P.I, mç. 25 , doc. 15

CC, P.I, mç 26, doc. 83

CC, P.I, mç. 27, doc. 36

CC, P.I, mç. 27 , doc. 41

CC, P.I, mç. 27, doc. 65

CC, P.I, mç. 27, doc. 66

CC, P.I, mç. 29, doc. 2

CC, P.I, mç. 32, doc. 103

CC., P.I, mç. 49, doc. 86

CC, P.I, mç. 50, doc. 23

CC, P.I, mç. 57 , doc. 43

CC, P.I, mç. 111 , doc. 78

\section{Biblioteca do Paço Ducal de Vila Viçosa (BPDVV)}

Ms. XXXIX, Miscelânea

\section{Fontes impressas}

AFONSO X, o Sábio, Rei de Leão e Castela (1807), Las Siete Partidas del Rey Don Alfonso el Sabio, cotejadas com varios codices antiguos por la Real Academia de la Historia, 3 Tomos, Madrid, Imprenta Real

ANDRADA, Francisco de (1976), Crónica de D. João III, Introdução e Revisão de Manuel Lopes de Almeida, Porto: Lello \& Irmão

CAMÕES, Luís de [1572], (ed. s/d), Os Lusíadas, $3^{\text {a }}$ edição, organizada por Emanuel Paulo Ramos, Porto: Porto Editora

CASTILHO, António de, (1970), "Crónica de D. João III”, ed. Joaquim Veríssimo Serrão, in Arquivos do Centro Cultural Português, vol. II, Paris: FCG, pp. 317-403

Chancelaria da Rainha D. Maria, $2^{a}$ mulher de El-rei D. Manuel. Manuscrito Inédito (1933), publicado com prefácio, notas e índices por Rogério de Figueiroa Rego, Oeiras: Miscelânea

Colecção de São Lourenço (1973), vol. I, Prefácio e Notas de Elaine Sanceau, Lisboa: Centro de Estudos Históricos Ultramarinos

"Contrato de casamento da Infante D. Brites com Carlos, Duque de Saboya" (1948), Provas de História Genealógica da Casa Real Portuguesa, publicadas por António Caetano de Sousa, nova edição revista por Manuel Lopes de Almeida e César Pegado, Tomo II, II Parte, Coimbra: Atlântida, pp. 18-26

CORREIA, Gaspar (1921), Lendas da Índia, T. I, Coimbra: Imprensa da Universidade 
(1992), Crónicas de D. Manuel e de D. João III (até 1533), Leitura, Introdução, notas e índice por José Pereira da Costa, Lisboa: Academia das Ciências

Correspondance (La) des Premiers Nonces Permanents au Portugal (1532-1553)(1980), vol. II - Textos, edição crítica e notas por Charles-Martial De Witte, Lisboa: Academia Portuguesa de História

Cortes Portuguesas. Reinado de D. Manuel I (Cortes de 1502) (2001), org. e revisão de João José Alves Dias, Lisboa: Centro de Estudos Históricos da UNL

Ditos Portugueses Dignos de Memória. História Íntima do século XVI (1997), edição anotada e comentada por José Hermano Saraiva, $3^{a}$ edição, Lisboa: Europa-América

"Dote da Duqueza Infante D. Beatriz" (1948), Provas de História Genealógica da Casa Real Portuguesa, publicadas por António Caetano de Sousa, nova edição revista por Manuel Lopes de Almeida e César Pegado, Tomo II, II Parte, Coimbra: Atlântida, pp.27-81

GALVÃO, Duarte (1986), Crónica de El-Rei D. Afonso Henriques, Apresentação de José Mattoso, Lisboa: IN-CM

Gavetas (As) da Torre do Tombo (1962, 1964,1967, 1974), vols. II, VI, VI, X, Lisboa: Centro de Estudos Históricos Ultramarinos

GÓIS, Damião de, (1949-1955), Crónica do Felicíssimo Rei D. Manuel, nova edição conforme a primeira de 1566, 4 vols., Coimbra: Universidade de Coimbra

"Inventario da Guarda-Roupa de D. Manuel" (1904), publ. por Anselmo Braamcamp Freire, in Archivo Historico Portuguez, vol. II, pp. 381-417

Letters of John III King of Portugal 1521-1557, (1931), texto português, com edição e introdução por J.D.M.Ford, Cambridge, Mass.: Harvard University Press

LEONIS Vercellensis, Petrus [1521] In Illustrissimorum Karoli Principis Sabaudiae Ducis E Beatricis Portugallensis auspicatissimis nuptiis Ephithalamion: [Milão]. Ex.da BPDVV, cota BDMII 60

Livro de Horas de D. Manuel, (1983), Estudo Introdutório de Dagoberto Markl, Lisboa: IN-CM

MENESES, Pedro de (1964), Oração proferida no Estudo Geral de Lisboa (Oratio Habita in Scholis Ulyxbonae), tradução de Miguel Pinto de Meneses, Introdução de A. Moreira de Sá, Lisboa: Instituto de Alta Cultura

OSÓRIO, Jerónimo (2004), Da Vida e Feitos de El-Rei D. Manuel, vol. XXVII de Biografias da História de Portugal. D. Manuel I, coord. José Hermano Saraiva, Matosinhos: Quidnovi

Relações de Pero de Alcáçova Carneiro, Conde da Idanha, do tempo que ele e seu pai, António Carneiro, serviram de secretários (1515 a 1568) (1937), publicação, revisão e notas por Ernesto de Campos de Andrada, Lisboa: Imprensa Nacional

RESENDE, Garcia de (1991), "A entrada del Rey Dom Manoel em Castella”, in Crónica de D. João II e Miscelânea por Garcia de Resende, reprodução fac-similada da nova edição conforme a de 1798, prefácio por Joaquim Veríssimo Serrão, Lisboa: IN-CM, pp. 297-318

(1991a), "Hida da Infanta Dona Beatriz pêra Saboya", in Crónica de D. João II e Miscelânea por Garcia de Resende, reprodução fac-similada da nova edição conforme a de 1798, prefácio por Joaquim Veríssimo Serrão, Lisboa: IN-CM, pp. 319-334

(1991b), "Miscellania [...] e variedade de historias, costumes, casos, e cousas que em seu tempo aconteceram", in Crónica de D. João II e Miscelânea por Garcia de Resende, reprodução fac-similada da nova edição conforme a de 1798, prefácio por Joaquim Veríssimo Serrão, Lisboa: IN-CM, pp. 335-381

SOUSA, António Caetano de (1947), História Genealógica da Casa Real Portuguesa, nova edição revista por M. Lopes de Almeida e César Pegado, T.III, Coimbra: Atlântida-Livraria Editora

SOUSA, António Caetano de (1947a), Provas da História Genealógica da Casa Real Portuguesa, nova edição revista por M. Lopes de Almeida e César Pegado, T.II, Parte I, Coimbra: Atlântida-Livraria Editora 
SOUSA, Frei Luís de (1938-54), Anais de D. João III, 2 vols., Prefácio e notas de Manuel Rodrigues Lapa, Lisboa: Sá da Costa

História de S. Domingos (1977), Introdução e revisão de M. Lopes de Almeida, 2 vols., Porto: Lello \& Irmão

Tratados Internacionales de España. Periodo de la Preponderancia Española, (1978), dir. Antonio Truyol y Serra, Carlos V, vol. I - España-Portugal, por P. Mariño, colab. de M. Moran, Madrid: CSIC]

VICENTE, Gil (1984), Copilaçam de Todalas Obras de Gil Vicente, Introdução e normalização do texto de Maria Leonor Carvalhão Buescu, vol. 2, Lisboa: IN-CM

\section{Estudos}

ALÇADA, João Nuno (1999), "As 'sortes ventureiras' do Auto das Fadas de Gil Vicente e o Libro delle Sorti o delle Venture de Lorenzo Spirito", in Arquivos do Centro Cultural Calouste Gulbenkian, vol. XXXVIII, Lisboa-Paris: FCG/CCCG, pp. 123-158

ALVES, Ana Maria (s/d) As Entradas Régias Portuguesas. Uma visão de conjunto, Lisboa: Livros Horizonte

ALVES, Ana Maria (1985), Iconologia do poder real no período manuelino. À procura de uma linguagem perdida, Lisboa: IN-CM

ALVES, José da Felicidade (1989 e 1991), O Mosteiro dos Jerónimos, vol. I - Descrição e evocação, vol. II - Das Origens à actualidade, Lisboa: Livros Horizonte

ANDRADE, Manuel Vaz Ferreira de (s/d), Palácios Reais de Lisboa (Os dois Paços de Xabregas, o de S. Bartolomeu e o de Alcáçova), Apresentação e índices de Maria Abel e Carlos Consiglieri, $2^{a}$ edição, fac-similada da edição de 1949, Lisboa: Vega

BARKER, Richard (s/d), "Showing the flag in 1521: wafting Beatriz to Savoy" (versão corrigida do artigo publ. in As novidades do mundo; conhecimento e representação na Época Moderna, Lisboa: Colibri, 2003)

BARROS, Carlos Vitorino da Silva (1983) O Vitral em Portugal. Séculos XV-XVI, Lisboa: XVII ${ }^{a}$ Exposição Europeia de Arte, Ciência e Cultura do Conselho da Europa, Os Descobrimentos Portugueses e a Europa do Renascimento

BEDINI, Silvio A. (1997), The Pope's Elephant, Manchester/Lisboa: Carcanet/FCG e CNCDP

BENNASSAR, Bartolomé (2009), A cama, o poder e a morte. Rainhas e princesas da Europa do Renascimento ao Iluminismo, Lisboa: Temas e Debates

BERTINI, Giuseppe (1989), "Le miniature farnesiane", FMR, n 74, Milão: Franco Maria Ricci Editore, pp. 83-91

BERTINI, Giuseppe (2000), "The Marriage of Alessandro Farnese and D. Maria de Portugal in 1565: Court Life in Lisbon and Parma”, in Cultural Links Between Portugal and Italy in the Renaissance, edited by K. J. P. Lowe, Oxford: OUP, pp. 45-59

BINSKI, Paul (1996) Medieval Death. Ritual and Representation, Londres: British Museum Press

BÜHLER, Curt (1973), "An Epithalamium on the Marriage of Charles III Savoy and Beatrice of Portugal" (1973), in Early Books and Manuscripts, Nova Iorque: Grolier Club, pp. 109-114

BUESCU, Ana Isabel (2007), Catarina de Áustria (1507-1578), Infanta de Tordesilhas, Rainha de Portugal, Lisboa: A Esfera dos Livros

BUESCU, Ana Isabel (2008), D. João III (1502-1557), Lisboa: Temas \& Debates 
BUESCU, Ana Isabel (2010), "Educar o príncipe no século xvI. Modelos, práticas e representações", in Na corte dos Reis de Portugal. Saberes, ritos e memórias, Lisboa: Edições Colibri

CAETANO, Joaquim de Oliveira (2010), "Lisboa, a grande oficina", in Primitivos Portugueses 1450-1550. O século de Nuno Gonçalves, Catálogo da Exposição (MNAA, 11 de Nov. de 2011- 27 de Fev. de 2011, ME, 18 de Nov. de 2010-27 de Fev. de 2011), comissário José Alberto Seabra Carvalho, Lisboa: MNAA/Athena, pp. 200-227

CARDoso, José Maria Pedrosa (2004), "A herança musical de D. Manuel I: novos dados para o conhecimento da Capela Real no século xvI", in III Congresso Histórico de Guimarães. D. Manuel e a sua Época (24-27 de Outubro de 2001). Actas, vol. IV, Arte e Cultura, Guimarães: Câmara Municipal de Guimarães, pp. 201-218.

CASTILHO, Júlio de (1893), A Ribeira de Lisboa: descripção historica da margem do Tejo desde a Madre-de-Deus até Santos-o-Velho, Lisboa: Imprensa Nacional

CHAMBerS, D. S. (2000), "Venetian Perceptions of Portugal c. 1500", in Cultural Links between Portugal and Italy in the Renaissance, edited by K.J.P. Loewe, Oxford: OUP, pp.19-43

CHAUnU, Pierre e Michèle ESCAMILla (2000), Charles Quint, Paris: Fayard

ClARETTA, Gaudenzio (1863), Notizie Storiche introno alla vitae ed al tempi de Beatrice di Portogallo duchessa di Savoia con documenti, Torino

COSTA, Abel Fontoura da (1937), Deambulações da Ganda de Modafar, Rei de Cambaia, de 1514 a 1516, Lisboa: Agência Geral das Colónias

COSTA, João Paulo de Oliveira (2005), D. Manuel I 1469-1521. Um Príncipe do Renascimento, Lisboa: Círculo de Leitores

CRUZ, Maria Augusta Lima (2006), D. Sebastião, Lisboa: Círculo de Leitores

DESWARTE, Sylvie (1991), "Espoirs et désespoir de l'infant D. Luís», Mare Liberum, 3, Lisboa: pp. 243-298

DIAS, João José Alves (2005), "Principais sismos, em Portugal, anteriores ao de 1755", in O grande Terramoto de Lisboa, vol. 1 Lisboa: FLAD e Público, pp. 123-142.

Exotica. The Portuguese Discoveries and the Renaissance Kunstkammer (2001), Catálogo da Exposição (Museu Calouste Gulbenkian e Kunsthistorisches Museum, 17 Out $^{\circ}$ 2001- 6 Janeiro 2002), Lisboa: FCG

Exposição (XVII) Europeia de Arte, Ciência e Cultura (1983), Os Descobrimentos portugueses e a Europa do Renascimento. A Dinastia de Avis (Casa dos Bicos) Lisboa: Presidência do Conselho de Ministros-Comissariado para a XVII Exposição Europeia de Arte, Ciência e Cultura

FERNANDES, Maria de Lurdes Correia (1995), Espelhos, Cartas e Guias. Casamento e espiritualidade na Península Ibérica 1450-1700, Porto: Faculdade de Letras, Instituto de Cultura Portuguesa

FERNANDES, Maria de Lurdes Correia (2004), "D. Maria, mulher de D. Manuel I: uma face esquecida da Corte do Venturoso", III Congresso Histórico de Guimarães. D. Manuel e a sua Época (24-27 de Outubro de 2001), Actas, vol. IV - Arte e Cultura, Guimarães: Câmara Municipal de Guimarães, pp. 21-32

FERNÁNDEZ ÁlVAREZ, Manuel (2002), Juana la Loca. La cautiva de Tordesillas, $17^{a}$ edição, Madrid: Espasa Calpe

FERNÁNDEZ ÁlVAREZ, Manuel (2003), Carlos V, el César y el Hombre, $15^{a}$ edição, Madrid: Espasa Calpe

FERNÁNDEZ ÁlVAREZ, Manuel (2003a), Isabel la Católica, Madrid: Espasa Calpe

FERREIRA, Ana Maria Pereira, (1995) Problemas marítimos entre Portugal e a França na primeira metade do século XVI, Redondo, Patrimonia 
FERreira Manuel Pedro (2008), Antologia da Música em Portugal na Idade Média e no Renascimento, vol. I - Textos e ilustrações, Introdução, coordenação e direcção musical de Manuel Pedro Ferreira, Lisboa: Arte das Musas

FLOR, Pedro (2010), A arte do retrato em Portugal nos séculos XV e XVI, Lisboa: Assírio e Alvim FORNASERI, Giovanni (1957), Beatrice di Portogallo, duchessa di Savoia: 1504-1538, Cuneo

France (La) de la Renaissance. Histoire et Dictionnaire, (2001), por Jouanna, Arlette, Philippe Hamon, Dominique Bilogi, Guy Le Thiec, Paris: Robert Laffont

FREIRE, Anselmo Braamcamp (1920), Ida da imperatriz dona Isabel para Castela, Coimbra: Imprensa da Universidade

FREIRE, Anselmo Braamcamp (1973), Brasões da Sala de Sintra, 3 vols., Lisboa: IN-CM

FREIRE, Anselmo Braamcamp (1944), Vida e Obra de Gil Vicente 'Trovador e Mestre da Balança', Lisboa, Edição da Revista Ocidente

GIORGI, Rosa (2003), Les Saints, Paris: Hazan

GODINHO, Vitorino Magalhães (1979), "Portugal no começo do século xvi: instituições e economia. O relato do veneziano Lunardo de Cà Masser", Revista de História Económica e Social, 4, pp. 75-88

GOMES, Rita Costa (1995), A Corte dos Reis de Portugal no final da Idade Média, Lisboa: Difel

GOMES, Rita Costa (1998), "Monarquia e território: residências reais portuguesas, séculos XIV a XvI", in Lugares de Poder, coordenação de Gérard Sabatier e Rita Costa Gomes, Lisboa: FCG / Acarte, pp. 84-102

GONÇALVES, Iria (1996), "Na Ribeira de Lisboa, em finais da Idade Média", in Um Olhar sobre a Cidade Medieval, Cascais: Patrimonia, pp. 61-75

GONÇALVES, Iria (2010), "O nome" in História da Vida Privada em Portugal, dir. José Mattoso, A Idade Média, coord. Bernardo Vasconcelos e Sousa, Lisboa: Temas e Debates, pp. 198-225

HerCulano, Alexandre (s/d), Opúsculos, vol. VI, Controversias e Estudos Historicos (Tomo III), $5^{a}$ edição, Lisboa: Bertrand

História da Europa Oxford (2009), coord. T.C.W. Blanning, O Século XVI, coord. de Euan Cameron, Porto: O Fio da Palavra

História de Portugal (1993), dir. José Mattoso, vol. 3 - No Alvorecer da Modernidade (1480-1620), coord. Joaquim Romero Magalhães, Lisboa: Círculo de Leitores

JACQUART, Jean (1994), François Ier, Paris: Fayard

JORDAN, Anne-Marie (1996), "As Maravilhas do Oriente: Colecções de Curiosidades Renascentistas em Portugal / The Marvels of the East: Renaissance Curiosity Collections in Portugal", in A Herança de Rauluchantim / The Heritage of Rauluchantim, Exposição e Catálogo, Lisboa: Museu de São Roque, pp. 82-127

JORDAN, Anne-Marie Retrato de corte em Portugal. O legado de António Moro (1552-1572) (1994), Lisboa: Quetzal

JUNCEDA AVELLO, Enrique (1995), Ginecología y vida íntima de las reinas de España, Tomo I - De Isabel la Catolica a la Casa de Borbon, Madrid, Ediciones Temas de Hoy

LADERO QUESADA, Miguel Ángel (2003), La España de los Reyes Católicos, Madrid: Alianza Editorial

LAMAS, Arthur (1916), Medalhas Portuguesas e estrangeiras referentes a Portugal, Lisboa, ed. autor

LOUDA, Jirí e Michael MACLAGAN (1984), Les Dynasties d'Europe. Héraldique et généalogie des familles impériales et royales, Paris: Bordas

MANSON, Michel (2002), História do Brinquedo e dos Jogos. Brincar através dos tempos, Lisboa: Teorema 
MARQUES, A. H. de Oliveira (1981), A Sociedade Medieval Portuguesa. Aspectos de Vida Quotidiana, $4^{\mathrm{a}}$ edição, Lisboa: Sá da Costa

MARQUES, A. H. de Oliveira (1994), "Depois da Reconquista. A cidade na Baixa Idade Média”, in O Livro de Lisboa, coordenação de Irisalva Moita, Lisboa: Livros Horizonte, pp. 89-113

MARTIN FERREIRA, Ana Isabel (2003), "Condición femenina y pedagogia en los textos médicos del siglo xvi", in La voz del olvido: Mujeres en la bistoria, Valladolid: Universidad de Valladolid, pp. 113-139

MARTINS, Maria Odete Sequeira (2009), Dona Brites. Uma mulher da Casa de Avis, Lisboa: Quidnovi

MAZARÍO COLETO, Maria del Cármen (1951), Isabel de Portugal, Emperatriz y Reina de España, Madrid: CSIC

MOITA, Irisalva (1994), "Lisboa no século xvi: a cidade e o ambiente" (1994), in O Livro de Lisboa, coordenação de Irisalva Moita, Lisboa: Livros Horizonte, pp. 139-167

MOURA, Vasco Graça, (1990), "Os retratos de Isabel”, Oceanos, 3, pp. 35-47

Mundo (Do) Antigo aos Novos Mundos. Humanismo, Classicismo e Notícias dos Descobrimentos em Évora (1516-1624), (1998), Catálogo da Exposição, Lisboa: CNCDP

NEVES, José Cassiano (1959), Damas portuguesas nas Cortes de Castela e de Sabóia no século XVI (duas irmãs, D. Leonor e D. Beatriz de Mascarenhas), sep. da Revista Ocidente, vol. LVII

OLIVA, Gianni (1998), I Savoia. Novecento anni di una dinastia, Milão: Mondadori

Outro Mundo Novo Vimos (2001), Exposição e Catálogo, Lisboa: CNCDP

OLIVEIRA, Julieta Teixeira Marques de (2000), Veneza e Portugal no século xvi: subsídios para a sua bistória, Lisboa: CNCDP/IN-CM

PALLA, Maria José (1996), "Figuras literárias de magas e imagens do sabat na obra de Gil Vicente", in A palavra e a imagem. Ensaios sobre Gil Vicente e a pintura quinhentista, Lisboa: Editorial Estampa, pp. 101-116

PELÚCIA, Alexandra (2004), "A baronia do Alvito e a Expansão manuelina no Oriente ou a reacção organizada à política imperialista”, in A Alta Nobreza e a Fundação do Estado da Índia. Coloquio Internacional. Actas, Lisboa, ed. João Paulo Oliveira e Costa e Vítor Luís Gaspar Rodrigues, CHAM -UNL, 2004, pp. 279-302.

PESTANA, Sebastião (1965), Contribuição para o estudo das 'Cortes de Júpiter', de Gil Vicente" (Estudos GilVicentinos - XXXVI), sep. da Revista Ocidente, vol. LXIX, Lisboa

PEREIRA, João Castel-Branco (2000), "Posteridades do efémero", in Arte Efémera em Portugal, Catálogo da Exposição, Lisboa: FCG, pp. 8-13

PEREIRA, Paulo (1995), "A simbólica manuelina. Razão, celebração, segredo", in História da Arte Portuguesa, dir. Paulo Pereira, vol. II - Do "Modo" gótico ao Maneirismo, Lisboa, Círculo de Leitores, pp. 115-155

PÉREZ, Joseph (2001), Los Comuneros, $3^{\text {a }}$ edição, Madrid: La Esfera de los Libros

POLÓNIA, Amélia (2005), D. Henrique. O Cardeal-Rei, Lisboa: Círculo de Leitores

RAMAlHO, Américo da Costa (1980), Estudos sobre o século xvi, Paris: FCG

RAmalho, Américo da Costa (1988), Para a História do Humanismo em Portugal, 2 vols., Coimbra: INIC, Lisboa: FCG e JNICT

RAMAlHO, Américo da Costa (1988a) Para a História do Humanismo em Portugal (III), Lisboa: IN-CM

RESENDE, Vasco (2004), "A armada de socorro aos Venezianos (1501) e o interesse português pelo Mediterrâneo no princípio do século xvi”, Clio. Revista do Centro de História da Universidade de Lisboa, 10, pp. 65-79 
RICE, Eugene F. e GRAFTON, Anthony (1994), The Foundations of Early Modern Europe 1460$-1559,2^{\text {nd }}$ ed., Nova Iorque/Londres: W.W. Norton \& Company

RODRIGUES, Maria Idalina Resina (2004), "Lisboa, 1521: as Cortes na corte", Península. Revista de Estudos Ibéricos, $\mathrm{n}^{\circ} 1$, pp. 37-51

SÁ, Isabel dos Guimarães (2007), "Up and Out. Children in Portugal and the Empire (1500-1800)", in Raising an Empire. Children in Early Modern Iberia and Colonial Latin America, ed. Ondina E. González e Bianca Premo, University of New Mexico Press

SABUGOSA, Conde de (1912), "D. Beatriz de Saboya", in Donas de Tempos Idos, Lisboa: Ferreira Editores, pp. 113-137

SALLMANN, Jean-Michel (2003), Nouvelle Histoire des Relations Internationales, 1 - Géopolitique du XVIe siècle 1490-1618, Paris: Seuil

SÃO PAYO, Conde de (D. António) (1930), Os que foram para Saboia com a Infanta Duqueza, Lisboa

SCHIANCHI, Maria Lucia (dir.) (1998), Galleria Nazionale di Parma. Catalogo sulle Opere. Il Cinquecento, Milano

SENOS, Nuno (2002), O Paço da Ribeira: 1501-1581, Lisboa: Editorial Notícias

SILVA, José Custódio Vieira da (2002), Paços Medievais portugueses, $2^{\mathrm{a}}$ edição, Lisboa: IPPAR

SILVA, João Ricardo Eusébio (2010), Estrela Clara de Aurora: Isabel de Portugal (1503-1539). Infância e educação de uma infanta de Portugal, dissertação de Mestrado em História Moderna e dos Descobrimentos apresentada à FCSH-UNL, Lisboa

SILVA, Nuno Vassalo e (1995), "A joalharia feminina em Portugal na época dos Descobrimentos", Oceanos, $\mathrm{n}^{\circ}$ 21, Jan $^{\circ}$-Março, pp. 102-110

SOUSA, António Caetano de (1948), História Genealógica da Casa Real Portuguesa, nova edição revista por Manuel Lopes de Almeida e César Pegado, T.II, II Parte, Coimbra: Atlântida

SOUSA, Ivo Carneiro de (2002), A rainha D. Leonor (1458-1525): poder, misericórdia, religiosidade e espiritualidade no Portugal do Renascimento, Lisboa: FCG/FCT

Tesouros da Biblioteca Nacional (1992), coord. de Maria Valentina C.A.Sul Mendes, Lisboa: Edições Inapa

TEYSSIER, Paul (1982), Gil Vicente - o Autor e a Obra, Lisboa: ICALP

THOMAZ, Luís Filipe F. R., (1990), "L’idée impériale manuéline”, in La Découverte, le Portugal et l'Europe, Actes du Colloque (Paris, 26-28 mai 1988), publ. por Jean Aubin, Paris: FCG, pp. 35-103

TRIGUEIROS, António Manuel (1985), Numismática e Medalbística. XVII Exposição de Arte, Ciência e Cultura, Os Descobrimentos Portugueses e a Europa do Renascimento: Lisboa

TRIGUEIROS, António Manuel (2010), "A medalha: Arte nobre da Escultura", Revista da Moeda, vol. 35,1 , pp. 17-26

VASCONCELOS, Carolina Michaëlis de (1949), Notas Vicentinas. Preliminares duma edição crítica das obras de Gil Vicente, Lisboa: ed. da Revista Ocidente

VITERBO, Francisco de Sousa (1892), Artes e artistas em Portugal. Contribuição para a historia das artes e industrias portuguesas, Lisboa: Livraria Ferreira

VITERBO, Francisco de Sousa (1908), O dote de D. Beatriz de Portugal Duqueza de Saboya, sep do Archivo Historico Portuguez, vol. VI, Lisboa

VITERBO, Francisco de Sousa (1914), "Amas, amos e collaços de pessoas reaes e de personagens illustres", Revista de Historia, n 9, Sociedade Portuguesa de Estudos Históricos, Jan-Março, pp. 52-67 